\title{
Copper(II) Complexes with Tetradentate Piperazine-Based Ligands: DNA Cleavage and Cytotoxicity
}

\author{
Sebastian Doniz Kettenmann ${ }^{1}$, Yvonne Nossol ${ }^{1}$, Febee R. Louka ${ }^{2}{ }^{\oplus}$, Julia R. Legrande ${ }^{2}$, Elise Marine ${ }^{2}$, \\ Roland C. Fischer $^{3}\left(\mathrm{D}\right.$, Franz A. Mautner ${ }^{4}$, Vinja Hergl ${ }^{1}$, Nora Kulak ${ }^{1,5, *(D)}$ and Salah S. Massoud ${ }^{2,6, *(D)}$ \\ 1 Institut für Chemie und Biochemie, Freie Universität Berlin, Fabeckstr. 34/36, 14195 Berlin, Germany; \\ doniz@zedat.fu-berlin.de (S.D.K.); yvonne_nossol@gmx.de (Y.N.); vmh@zedat.fu-berlin.de (V.H.) \\ 2 Department of Chemistry, University of Louisiana at Lafayette, P.O. Box 44370, Lafayette, LA 70504, USA; \\ febee.louka@louisiana.edu (F.R.L.); julia.legrande1@louisiana.edu (J.R.L.); elise.mdb@hotmail.fr (E.M.) \\ 3 Institut für Anorganische Chemische, Technische Universität Graz, Stremayrgasse 9/V, A-8010 Graz, Austria; \\ roland.fischer@tugraz.at \\ 4 Institut für Physikalische und Theoretische Chemie, Technische Universität Graz, Stremayrgasse 9/II, \\ A-8010 Graz, Austria; mautner@tugraz.at \\ 5 Institut für Chemie, Otto-von-Guericke-Universität Magdeburg, Universitätsplatz 2, \\ 39106 Magdeburg, Germany \\ 6 Department of Chemistry, Faculty of Science, Alexandria University, Moharem Bey, 21511 Alexandria, Egypt \\ * Correspondence: nora.kulak@ovgu.de (N.K.); ssmassoud@louisiana.edu (S.S.M.); \\ Tel.: +49-391-67-58327 (N.K.); +1-337-482-5672 (S.S.M.); Fax: +49-391-67-42933 (N.K.); \\ +1-337-482-5676 (S.S.M.)
}

\section{check for}

updates

Citation: Doniz Kettenmann, S.; Nossol, Y.; Louka, F.R.; Legrande, J.R.; Marine, E.; Fischer, R.C.; Mautner, F.A.; Hergl, V.; Kulak, N.; Massoud, S.S. Copper(II) Complexes with Tetradentate Piperazine-Based Ligands: DNA Cleavage and Cytotoxicity. Inorganics 2021, 9, 12. https://doi.org/10.3390/ inorganics 9020012

Received: 2 December 2020 Accepted: 29 December 2020 Published: 1 February 2021

Publisher's Note: MDPI stays neutral with regard to jurisdictional clai$\mathrm{ms}$ in published maps and institutional affiliations.

Copyright: (C) 2021 by the authors. Licensee MDPI, Basel, Switzerland. This article is an open access article distributed under the terms and conditions of the Creative Commons Attribution (CC BY) license (https:// creativecommons.org/licenses/by/ $4.0 /)$.

\begin{abstract}
Five-coordinate $\mathrm{Cu}(\mathrm{II})$ complexes, $\left[\mathrm{Cu}\left(\mathrm{L}^{\mathrm{n}}\right) \mathrm{X}\right] \mathrm{ClO}_{4} / \mathrm{PF}_{6}$, where $\mathrm{L}^{\mathrm{n}}=$ piperazine ligands bearing two pyridyl arms and $\mathrm{X}=\mathrm{ClO}_{4}{ }^{-}$for $\mathrm{L}^{\mathrm{n}}=\mathrm{L}^{1}\left(\mathbf{1}-\mathrm{ClO}_{4}\right), \mathrm{L}^{2}\left(\mathbf{2}-\mathrm{ClO}_{4}\right), \mathrm{L}^{3}\left(\mathbf{3}-\mathrm{ClO}_{4}\right)$, and $\mathrm{L}^{6}$ $\left(6-\mathrm{ClO}_{4}\right)$ as well as $\left[\mathrm{Cu}\left(\mathrm{L}^{\mathrm{n}}\right) \mathrm{Cl}\right] \mathrm{PF}_{6}$ for $\mathrm{L}^{\mathrm{n}}=\mathrm{L}^{1}(\mathbf{1}-\mathrm{Cl}), \mathrm{L}^{4}(4-\mathrm{Cl})$, and $\mathrm{L}^{5}(5-\mathrm{Cl})$ have been synthesized and characterized by spectroscopic techniques. The molecular structures of the last two complexes were determined by X-ray crystallography. In aqueous acetonitrile solutions, molar conductivity measurements and UV-VIS spectrophotometric titrations of the complexes revealed the hydrolysis of the complexes to $\left[\mathrm{Cu}\left(\mathrm{L}^{\mathrm{n}}\right)\left(\mathrm{H}_{2} \mathrm{O}\right)\right]^{2+}$ species. The biological activity of the $\mathrm{Cu}(\mathrm{II})$ complexes with respect to DNA cleavage and cytotoxicity was investigated. At micromolar concentration within $2 \mathrm{~h}$ and $\mathrm{pH} 7.4$, DNA cleavage rate decreased in the order: $1-\mathrm{Cl} \approx 1-\mathrm{ClO}_{4}>3-\mathrm{ClO}_{4} \geq 2-\mathrm{ClO}_{4}$ with cleavage enhancements of up to 23 million. Complexes $4-\mathbf{C l}, 5-\mathbf{C l}$, and $\mathbf{6}-\mathbf{C l O}_{4}$ were inactive. In order to elucidate the cleavage mechanism, the cleavage of bis(4-nitrophenyl)phosphate (BNPP) and reactive oxygen species (ROS) quenching studies were conducted. The mechanistic pathway of DNA cleavage depends on the ligand's skeleton: while an oxidative pathway was preferable for $\mathbf{1 - C l} / \mathbf{1}-\mathrm{ClO}_{4}, \mathrm{DNA}$ cleavage by $2-\mathrm{ClO}_{4}$ and $3-\mathrm{ClO}_{4}$ predominantly proceeds via a hydrolytic mechanism. Complexes $\mathbf{1}-\mathrm{ClO}_{4}, \mathbf{3}-\mathrm{ClO}_{4}$, and $\mathbf{5}-\mathrm{Cl}$ were found to be cytotoxic against A2780 cells $\left(\mathrm{IC}_{50} 30-40 \mu \mathrm{M}\right)$. In fibroblasts, the $\mathrm{IC}_{50}$ value was much higher for $3-\mathrm{ClO}_{4}$ with no toxic effect.
\end{abstract}

Keywords: copper; DNA cleavage; phosphodiester; cytotoxicity; piperazine

\section{Introduction}

Deoxyribonucleic acid (DNA) is known to play an important role in the survival and maintenance of life on earth as it stores the genetic information for cellular functions. The stability and resistance of the phosphodiester bonds in DNA towards hydrolytic cleavage under physiological conditions is remarkable, considering that the half-life time of this process was estimated to be about 130,000 years [1,2]. However, nature developed its own enzymes, which efficiently and rapidly catalyze the hydrolytic cleavage of $\mathrm{P}-\mathrm{O}$ bonds in DNA. To mimic the biological function of these enzymes, many artificial nucleases based on transition metal complexes with different metal ions, oxidation states, ligand skeletons, geometrical structures, and solubility in aqueous medium have been developed to study 
the $\mathrm{P}-\mathrm{O}$ bond cleavage in DNA. The metal ions include $\mathrm{Co}(\mathrm{II})$ and $\mathrm{Co}(\mathrm{III}), \mathrm{Ru}(\mathrm{II})$ and $\mathrm{Ru}(\mathrm{III}), \mathrm{Mo}(\mathrm{V}), \mathrm{Zn}(\mathrm{II})$, and $\mathrm{Cu}(\mathrm{II})$ [3-26]. Some $\mathrm{Co}(\mathrm{II})$ and $\mathrm{Cu}(\mathrm{II})$ compounds revealed dramatic enhancement for the catalytic cleavage of DNA under mild conditions by a factor greater than 100 million times compared to the noncatalyzed cleavage with mechanistic pathways proceeding through hydrolytic, oxidative, or both mechanisms [3,4,22-26].

On the other hand, metal-based pharmaceuticals are of considerable interest due to their potential application as anticancer agents. Aside from the tremendous success of platinum-based drugs in the treatment of different carcinogenic tumors [27-29], the serious side effects and drug resistance phenomena have limited the use of these compounds $[27,30,31]$. Therefore, there is a continuous and acute need in cancer therapy for the design of alternative chemotherapeutic agents based on metals other than platinum, which show improved pharmacological properties of high selective cytotoxicity. Recently, it was demonstrated in our laboratory and by other groups that copper complexes with various ligand skeletal and geometrical structures showed significantly higher cytotoxicity as anticancer agents than platinum compounds like cisplatin [32-42].

In general, anticancer agents, which damage DNA or block its replication, are often taken as preliminary indicators for its potential clinical suitability [43]. Therefore, studying the interaction between metal-based drugs and DNA is considered to be the crucial key step in understanding the mechanism of anticancer drugs. Several studies have suggested that DNA is the primary intracellular target of antitumor drugs because the interaction between small drug molecules and base pairs of DNA can cause DNA damage in cancer as this interferes with normal functioning of the enzyme topoisomerase II, which is involved in the breaking and releasing of DNA [27,29,37].

Herein, we report the synthesis and characterization of five-coordinate copper(II) complexes with piperazine bearing two pendant symmetrical pyridyl arms $\left(\mathrm{L}=\mathrm{L}^{1}, \mathrm{~L}^{2}, \mathrm{~L}^{4}, \mathrm{~L}^{5}\right.$ and $\mathrm{L}^{6}$ ) or quinolyl groups $\left(\mathrm{L}^{3}\right),[\mathrm{Cu}(\mathrm{L}) \mathrm{X}] \mathrm{ClO}_{4} / \mathrm{PF}_{6}\left(\mathrm{X}=\mathrm{Cl}, \mathrm{ClO}_{4}\right)$. Structures of the piperazine derivatives used in this study and their abbreviations are illustrated in Scheme 1. The DNA cleavage activity by the copper(II) complexes under near-physiological conditions and their cytotoxic activity against some cancer cell lines were the target of this study.<smiles>c1ccc(CN2CCN(Cc3ccccn3)CC2)nc1</smiles><smiles>Cc1cccc(CN2CCN(Cc3cccc(C)n3)CC2)n1</smiles><smiles>c1ccc2nc(CN3CCN(Cc4ccc5ccccc5n4)CC3)ccc2c1</smiles>
$\mathbf{L}^{1}$ $\mathbf{L}^{3}$<smiles>[CH]Oc1ccnc(CN2CCN(Cc3nccc(OC)c3OC)CC2)c1OC</smiles><smiles>COc1c(C)cnc(CN2CCN(Cc3ncc(C)c(OC)c3C)CC2)c1C</smiles><smiles>c1ccc(CCN2CCN(CCc3ccccn3)CC2)nc1</smiles>

Scheme 1. Structures and abbreviations of piperazine ligands used in this study.

\section{Results and Discussion}

\subsection{Syntheses}

A novel series of symmetrical tetradentate $N$-donor ligands (L) based on piperazine bearing different pyridyl substituents $\left(\mathrm{L}^{2}, \mathrm{~L}^{4}\right.$, and $\left.\mathrm{L}^{5}\right)$ or quinolyl group $\left(\mathrm{L}^{3}\right)$ were synthesized. The design of these ligands depends on increasing the steric environment around the piperazine base compared to the parent unsubstituted 1,4-bis[(2-pyridinyl)methyl]piperazi ne $\left(\mathrm{L}^{1}\right)$ compound (Scheme 1) [6]. The compounds were synthesized using a general method by refluxing a well-stirred mixture of piperazine and the hydrochloride salts of 
2-(chloromethyl)-pyridine derivatives or 2-(chloromethyl)-quinoline, in the stoichiometric ratio of 1:2, and a slight excess of anhydrous $\mathrm{K}_{2} \mathrm{CO}_{3}\left(\right.$ or $\mathrm{Et}_{3} \mathrm{~N}$ ) in dry $\mathrm{CH}_{3} \mathrm{CN}$ (or THF) under $\mathrm{N}_{2}$ gas. The compounds were extracted by $\mathrm{CH}_{2} \mathrm{Cl}_{2}$ and $10 \% \mathrm{NaOH}$ solution and recrystallized with the appropriate solvent with the aid of activated charcoal. While the yield of $\mathrm{L}^{2}$ was good (84\%), lower yields were obtained (42-54\%) for $\mathrm{L}^{3}-\mathrm{L}^{5}$. The isolated compounds were characterized by elemental microanalyses, IR, ${ }^{1} \mathrm{H}$, and ${ }^{13} \mathrm{C}$ NMR (Figures S1-S4 are given in the Supplementary), whereas in case of $\mathrm{L}^{2}$ and $\mathrm{L}^{3}$ (Figure S5), also by ESI-MS.

Although the syntheses of the $\mathrm{Cu}(\mathrm{II})$ complexes under investigation, $[\mathrm{Cu}(\mathrm{L}) \mathrm{X}] \mathrm{ClO}_{4} / \mathrm{PF}_{6}$ where $\mathrm{X}=\mathrm{ClO}_{4}$ for $\mathrm{L}=\mathrm{L}^{1}\left(\mathbf{1}-\mathrm{ClO}_{4}\right)[6], \mathrm{L}^{2}\left(\mathbf{2}-\mathrm{ClO}_{4}\right), \mathrm{L}^{3}\left(3-\mathrm{ClO}_{4}\right), \mathrm{L}^{6}\left(\mathbf{6}-\mathrm{ClO}_{4}\right)[6]$, and $\mathrm{X}=\mathrm{Cl}$ for $\left[\mathrm{Cu}\left(\mathrm{L}^{1}\right) \mathrm{Cl}\right] \mathrm{PF}_{6}(\mathbf{1}-\mathrm{Cl}),\left[\mathrm{Cu}\left(\mathrm{L}^{4}\right) \mathrm{Cl}\right] \mathrm{ClO}_{4} \cdot \frac{1}{2} \mathrm{H}_{2} \mathrm{O}(4-\mathrm{Cl})$, and $\left[\mathrm{Cu}\left(\mathrm{L}^{5}\right) \mathrm{Cl}\right] \mathrm{PF}_{6}(5-\mathrm{Cl})$ were straightforward, attempts to synthesize each pair of complexes with $\mathrm{X}=\mathrm{Cl}^{-}$and $\mathrm{ClO}_{4}{ }^{-}$ failed. Reactions of equimolar amounts of a methanolic solution containing $\mathrm{Cu}\left(\mathrm{ClO}_{4}\right)_{2} \cdot 6 \mathrm{H}_{2} \mathrm{O}$ or $\mathrm{CuCl}_{2} \cdot 2 \mathrm{H}_{2} \mathrm{O}$ and the corresponding appropriate ligand followed by the addition of $\mathrm{NaClO}_{4}$ or $\mathrm{NH}_{4} \mathrm{PF}_{6}$ afforded the desired products, which were further recrystallized from $\mathrm{CH}_{3} \mathrm{OH}$. Single crystals suitable for X-ray crystallography were obtained from dilute methanolic solutions. The synthesized complexes have limited solubility in $\mathrm{H}_{2} \mathrm{O}$, good solubility in $\mathrm{CH}_{3} \mathrm{OH}$, and are freely soluble in $\mathrm{CH}_{3} \mathrm{CN}$. The resulting $\mathrm{Cu}$ (II) complexes were characterized by IR and UV-VIS spectroscopy, elemental microanalyses, ESI-MS (Figures S6-S9), and by single crystal X-ray crystallography for $\left[\mathrm{Cu}\left(\mathrm{L}^{4}\right) \mathrm{Cl}^{-} \mathrm{ClO}_{4} \cdot \mathrm{H}_{2} \mathrm{O}(4-\mathrm{Cl})\right.$ and $\left[\mathrm{Cu}\left(\mathrm{L}^{5}\right) \mathrm{Cl}\right] \mathrm{PF}_{6}(5-\mathrm{Cl})$.

\subsection{Characterization of the Complexes}

\subsubsection{Crystal Structures of Complexes 4-Cl and 5-Cl}

It was possible to analyze single crystal $\mathrm{X}$-ray crystallographic data for the complexes $\left[\mathrm{Cu}\left(\mathrm{L}^{4}\right) \mathrm{Cl}\right] \mathrm{ClO}_{4} \cdot \mathrm{H}_{2} \mathrm{O}(4-\mathrm{Cl})$ and $\left[\mathrm{Cu}\left(\mathrm{L}^{5}\right) \mathrm{Cl}_{1} \mathrm{PF}_{6}(5-\mathrm{Cl})\right.$. Perspective views of the molecular structures of the $[\mathrm{Cu}(\mathrm{L}) \mathrm{Cl}]^{+}$complex cations of 4- $\mathrm{Cl}$ and 5-Cl (details of crystal structure determinations and crystallographic data and processing parameters (Table S1) are given in the Supplementary Material section) are depicted in Figure 1. The copper(II) centers are pentacoordinated by $4 \mathrm{~N}$-donor atoms of the substituted pyridyl piperazine molecule ( $\mathrm{Cu}-\mathrm{N}$ bond distances are in the range of 1.991 to $2.064 \AA)$ and one $\mathrm{Cl}^{-}$anion $(\mathrm{Cu}-\mathrm{Cl}$ bond lengths of 2.405 and $2.359 \AA$ for $4-\mathrm{Cl}$ and 5-Cl, respectively. The $\mathrm{CuLCl}$ polyhedrons in 4-Cl and 5- $\mathrm{Cl}$ form square pyramidal (SP) geometries, with almost perfect $\mathrm{SP}$ in the former complex $(\tau=0.02)$ and somewhat more distorted in $5-\mathrm{Cl}(\tau=0.19)$ [44].

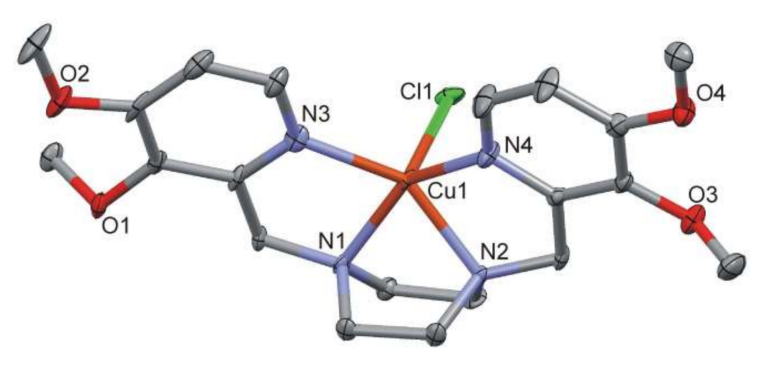

(a)

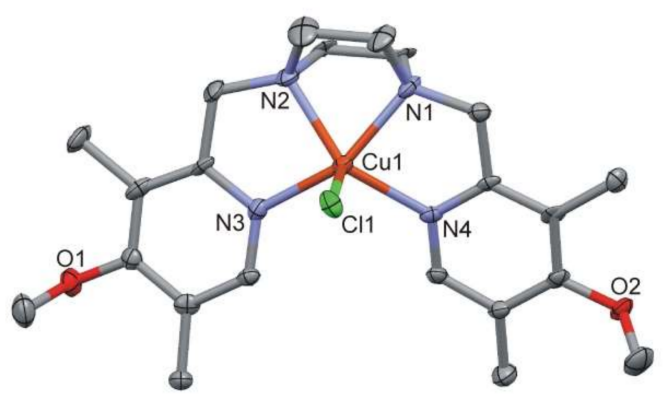

(b)

Figure 1. Molecular structures of complex cations of (a) 4-Cl and (b) 5-Cl.

The X-ray crystallography of the previously determined chlorido complex, $\left[\mathrm{Cu}\left(\mathrm{L}^{1}\right) \mathrm{Cl}\right]$ $\mathrm{ClO}_{4}$, and its corresponding acetonitrile complex, $\left[\mathrm{Cu}\left(\mathrm{L}^{1}\right)\left(\mathrm{CH}_{3} \mathrm{CN}\right)\right]\left(\mathrm{PF}_{6}\right)_{2}$ revealed that these molecules adopt square-pyramidal geometries $[6,45]$. 


\subsubsection{Spectroscopic and Molar Conductivity Characterization}

The IR spectra of the complexes under investigation display some general characteristic features, which include a series of weak to very weak bands over the frequency regions $3090-3000$ and $2990-2830 \mathrm{~cm}^{-1}$ attributable to $\mathrm{C}-\mathrm{H}$ stretching frequencies of the pyridyl and aliphatic $\mathrm{C}-\mathrm{H}$ groups, respectively. In some cases, the former series of bands were not observed because of their very weak intensities. Another series of medium intensity bands appeared in the range of $1610-1440 \mathrm{~cm}^{-1}$ due to the $\mathrm{C}=\mathrm{C}$ and $\mathrm{C}=\mathrm{N}$ stretching of the pyridyl rings. The spectra of complexes $\left[\mathrm{Cu}\left(\mathrm{L}^{4}\right) \mathrm{Cl}\right] \mathrm{ClO}_{4} \cdot \frac{1}{2} \mathrm{H}_{2} \mathrm{O}(4-\mathrm{Cl})$ and $\left[\mathrm{Cu}\left(\mathrm{L}^{5}\right) \mathrm{Cl}\right] \mathrm{PF}_{6}(5-\mathrm{Cl})$ displayed two bands of medium intensity in the range of $1300-1240 \mathrm{~cm}^{-1}$ due to $v_{\text {as }}(\mathrm{C}-\mathrm{O}-$ $\mathrm{CH}_{3}$ ) stretching vibration of the methoxy groups. Complex 4-Cl exhibits a medium broad intense band over the region of $3540-3420 \mathrm{~cm}^{-1}$ due to the $v_{\text {as }}(\mathrm{H}-\mathrm{O})$ stretching vibration of lattice water. The perchlorato complexes $\left[\mathrm{Cu}(\mathrm{L}) \mathrm{ClO}_{4}\right] \mathrm{ClO}_{4}\left(\mathbf{1}-\mathrm{ClO}_{4}: \mathrm{L}=\mathrm{L}^{1}, \mathbf{2}-\mathrm{ClO}_{4}: \mathrm{L}=\mathrm{L}^{2}\right.$, 3- $-\mathrm{ClO}_{4}: \mathrm{L}=\mathrm{L}^{3}$, and 6- $\mathrm{ClO}_{4}: \mathrm{L}=\mathrm{L}^{6}$ ) displayed two strong split bands around 1100 and 1050 $\mathrm{cm}^{-1}$ attributable to $v_{\text {as }}(\mathrm{O}-\mathrm{Cl})$ stretching vibrations of the coordinated and counter $\mathrm{ClO}_{4}{ }^{-}$ ions, whereas the bands observed at 1084 and $1052 \mathrm{~cm}^{-1}$ in $\left[\mathrm{Cu}\left(\mathrm{L}^{4}\right) \mathrm{Cl}^{2} \mathrm{ClO}_{4} \cdot \frac{1}{2} \mathrm{H}_{2} \mathrm{O}(4-\mathrm{Cl})\right.$ most likely result from the reduction of the symmetry of the $\mathrm{ClO}_{4}{ }^{-}$counter ion from $\mathrm{T}_{\mathrm{d}}$ to $\mathrm{C}_{3 v}$ or $\mathrm{C}_{2 v}$. The hexafluorophosphate complexes $\left[\mathrm{Cu}\left(\mathrm{L}^{1}\right) \mathrm{Cl}\right] \mathrm{PF}_{6}(\mathbf{1}-\mathrm{Cl})$ and $\left[\mathrm{Cu}\left(\mathrm{L}^{5}\right) \mathrm{Cl}\right] \mathrm{PF}_{6}$ $(5-\mathrm{Cl})$ revealed a single very strong band around $830 \mathrm{~cm}^{-1}$ attributable to $v(\mathrm{P}-\mathrm{F})$ stretching frequency of the $\mathrm{PF}_{6}{ }^{-}$counter ion. The medium intense band observed at $3547 \mathrm{~cm}^{-1}$ in $\left[\mathrm{Cu}\left(\mathrm{L}^{4}\right) \mathrm{Cl}\right] \mathrm{ClO}_{4} \cdot \frac{1}{2} \mathrm{H}_{2} \mathrm{O}(4-\mathrm{Cl})$ results from the $v(\mathrm{H}-\mathrm{O})$ stretching frequencies of lattice $\mathrm{H}_{2} \mathrm{O}$.

The UV-VIS spectra of the synthesized $\mathrm{Cu}$ (II) complexes recorded in $\mathrm{CH}_{3} \mathrm{CN}$ displayed a single broad band over the wavelength region of $645-770 \mathrm{~nm}$ for $[\mathrm{Cu}(\mathrm{L}) \mathrm{X}]^{+}\left(\mathrm{L}=\mathrm{L}^{1}-\mathrm{L}^{5}\right.$, $\mathrm{X}=\mathrm{ClO}_{4}{ }^{-}$or $\left.\mathrm{Cl}^{-}\right)$and at $583 \mathrm{~nm}$ for $\left[\mathrm{Cu}\left(\mathrm{L}^{6}\right) \mathrm{ClO}_{4}\right]^{+}$. The position of this band depends entirely on the ligand field strength of the tetraamine. The electronic spectra of the complexes in $\mathrm{CH}_{3} \mathrm{CN}$ are summarized in Table 1 together with their molar conductivity. Inspection of this data reveals that the complexes have similar spectral features. In general, the observed band is due to $\mathrm{d}-\mathrm{d}$ transition in five-coordinate $\mathrm{Cu}(\mathrm{II})-\mathrm{d}^{9}$ complexes. The presence of this band, which is associated with or without low-energy shoulder indicates a square pyramidal (SP) geometry, whereas the single $\mathrm{d}-\mathrm{d}$ band at $\lambda_{\max } \geq 850 \mathrm{~nm}$ with a high-energy shoulder is typical for trigonal bipyramidal (TBP) stereochemistry [46-49]. Thus, on the basis of this criterion, the spectral data of the complexes are consistent with distorted $\mathrm{SP}$, where the absorption maximum band observed in the visible region results from ${ }^{2} \mathrm{~B}_{1} \leftarrow{ }^{2} \mathrm{E}$ transition [46].

Table 1. Visible spectral and molar conductivity data for the chlorido and perchlorato $\mathrm{Cu}(\mathrm{II})$-based piperazine pyridyl complexes, $[\mathrm{Cu}(\mathrm{L}) \mathrm{X}] \mathrm{ClO}_{4} / \mathrm{PF}_{6}$ in solution.

\begin{tabular}{|c|c|c|c|c|}
\hline \multirow[t]{2}{*}[\mathrm{Cu}(\mathrm{L})\mathrm{X}]{$\mathrm{ClO}_{4} / \mathrm{PF}_{6}$} & & $\lambda_{\max }\left(\varepsilon_{\max }, \mathbf{M}^{-1} \mathrm{~cm}^{-1}\right)$ & $\Lambda_{M}\left(\Omega^{-1} \cdot \mathrm{cm}^{2} \cdot \mathrm{mol}^{-1}\right)$ & $\Lambda_{M}\left(\Omega^{-1} \cdot \mathrm{cm}^{2} \cdot \mathrm{mol}^{-1}\right)$ \\
\hline & & $\mathrm{CH}_{3} \mathrm{CN}$ & $\mathrm{CH}_{3} \mathrm{CN}$ & $\left(\mathrm{CH}_{3} \mathrm{CN} / \mathrm{H}_{2} \mathrm{O} 1: 1 \mathrm{v} / \mathrm{v}\right)$ \\
\hline$\left[\mathrm{Cu}\left(\mathrm{L}^{1}\right) \mathrm{ClO}_{4}\right] \mathrm{ClO}_{4}$ & $\left(1-\mathrm{ClO}_{4}\right)$ & $645(310)$ & 300 & 213 \\
\hline$\left[\mathrm{Cu}\left(\mathrm{L}^{2}\right) \mathrm{ClO}_{4}\right]_{\mathrm{ClO}}$ & $\left(2-\mathrm{ClO}_{4}\right)$ & $\sim 752(299)$ & 297 & 189 \\
\hline$\left[\mathrm{Cu}\left(\mathrm{L}^{3}\right) \mathrm{ClO}_{4}\right] \mathrm{ClO}_{4}$ & $\left(3-\mathrm{ClO}_{4}\right)$ & $\begin{array}{l}\sim 565(\mathrm{sh}), \sim 618(\mathrm{sh}), 745 \\
(226)\end{array}$ & 301 & 188 \\
\hline$\left[\mathrm{Cu}\left(\mathrm{L}^{6}\right) \mathrm{ClO}_{4}\right] \mathrm{ClO}_{4}$ & $\left(6-\mathrm{ClO}_{4}\right)$ & $583(237)$ & 304 & 184 \\
\hline$\left[\mathrm{Cu}\left(\mathrm{L}^{1}\right) \mathrm{Cl}\right] \mathrm{PF}_{6}$ & $(1-\mathrm{Cl})$ & $770(304)$ & 160 & 171 \\
\hline$\left[\mathrm{Cu}\left(\mathrm{L}^{4}\right) \mathrm{Cl}\right] \mathrm{ClO}_{4} \cdot \frac{1}{2} \mathrm{H}_{2} \mathrm{O}$ & $(4-\mathrm{Cl})$ & $771(324)$ & 145 & 168 \\
\hline$\left[\mathrm{Cu}\left(\mathrm{L}^{5}\right) \mathrm{Cl}\right] \mathrm{PF}_{6}$ & $(5-\mathrm{Cl})$ & $765(352)$ & 162 & 177 \\
\hline
\end{tabular}

The molar conductivity of the chlorido and perchlorato complexes, measured in acetonitrile, provided interesting results. The molar conductivities of $\left[\mathrm{Cu}(\mathrm{L}) \mathrm{Cl}^{-} \mathrm{ClO}_{4} / \mathrm{PF}_{6}(\mathbf{1}-\mathrm{Cl}\right.$, 4- $\mathrm{Cl}$, and 5-Cl), in the range of $\Lambda_{\mathrm{M}}=145-162\left(\Omega^{-1} \cdot \mathrm{cm}^{2} \cdot \mathrm{mol}^{-1}\right)$ (Table 1) are in complete agreement with their predicted 1:1 electrolytic nature [50]. Unlike the chlorido compounds, 
the corresponding perchlorato complexes, $\left[\mathrm{Cu}(\mathrm{L}) \mathrm{ClO}_{4}\right] \mathrm{ClO}_{4}\left(\mathbf{1}-\mathrm{ClO}_{4}-\mathbf{3}-\mathrm{ClO}_{4}\right.$ and $\left.\mathbf{6}-\mathrm{ClO}_{4}\right)$ in $\mathrm{CH}_{3} \mathrm{CN}$ revealed conductivity values of $\Lambda_{\mathrm{M}} \sim 300 \Omega^{-1} \cdot \mathrm{cm}^{2} \cdot \mathrm{mol}^{-1}$, which are fully consistent with the formation of 1:2 electrolytes [50]. This result evidently shows that the perchlorato compounds undergo solvolysis in $\mathrm{CH}_{3} \mathrm{CN}$ with the release of $\mathrm{ClO}_{4}{ }^{-}$ions and the formation of $\left[\mathrm{Cu}(\mathrm{L})\left(\mathrm{CH}_{3} \mathrm{CN}\right)\right]^{2+}$ species in solution. This finding was confirmed by the isolation and characterization of $\left[\mathrm{Cu}\left(\mathrm{L}^{1}\right)\left(\mathrm{CH}_{3} \mathrm{CN}\right)\right]\left(\mathrm{PF}_{6}\right)_{2}[45]$.

\subsubsection{Solution Study and Stability of Complexes}

The visible spectra of the complexes under investigation and their molar conductivity, $\Lambda_{\mathrm{M}}$, were examined in $\mathrm{CH}_{3} \mathrm{CN}$ and aqueous acetonitrile solutions, and measurements were conducted over a period of 1 week. As indicated above, the electronic spectra of the complexes in $\mathrm{CH}_{3} \mathrm{CN}$ solution suggest distorted square pyramidal geometry as all produce similar spectral patterns with a single broad band over the wavelength range of $645-770 \mathrm{~nm}$. This band did not show any sign of spectral changes over a period of 1 week. The molar conductivities of the perchlorato complexes $1-\mathrm{ClO}_{4}-\mathbf{3}-\mathrm{ClO}_{4}$ $\left(\Lambda_{\mathrm{M}}=300-310 \Omega^{-1} \cdot \mathrm{cm}^{2} \cdot \mathrm{mol}^{-1}\right)$ and the corresponding chlorido complexes 1-Cl, 4- $\mathrm{Cl}$, and 5-Cl $\left(\Lambda_{\mathrm{M}}=145-171 \Omega^{-1} \cdot \mathrm{cm}^{2} \cdot \mathrm{mol}^{-1} ;[\mathrm{Cu}(\mathrm{L}) \mathrm{Cl}]^{+}+\mathrm{ClO}_{4}{ }^{-} / \mathrm{PF}_{6}{ }^{-}\right)$(Table 1$)$ were in agreement with 1:2 and 1:1 electrolytes, respectively. The conductivity behavior observed in the former case can be explained on the basis of displacement of the coordinated $\mathrm{ClO}_{4}{ }^{-}$ ion by $\mathrm{CH}_{3} \mathrm{CN}$ and the formation of $\left[\mathrm{Cu}(\mathrm{L})\left(\mathrm{CH}_{3} \mathrm{CN}\right)\right]^{2+}$ species (Scheme 1); the chlorido complexes retained their identities in pure $\mathrm{CH}_{3} \mathrm{CN}$ solution.

In contrast, the dissolution of the perchlorato or the chlorido complexes, $[\mathrm{Cu}(\mathrm{L}) \mathrm{X}] \mathrm{ClO}_{4} /$ $\mathrm{PF}_{6}\left(\mathrm{X}=\mathrm{ClO}_{4}^{-}\right.$or $\left.\mathrm{Cl}^{-}\right)$in aqueous acetonitrile solutions is instantaneously associated with color change from teal or blue to aqua blue or cyan, and this process is accompanied by a blue shift in the visible region. Some examples are represented in Figure 2 in $\mathrm{CH}_{3} \mathrm{CN}$ and $\mathrm{CH}_{3} \mathrm{CN} / \mathrm{H}_{2} \mathrm{O}$ (1:1 by volume) solutions. Interestingly, the original molar conductivity values of the perchlorato complexes, $\left[\mathrm{Cu}(\mathrm{L}) \mathrm{ClO}_{4}\right]^{+}$, which were measured in pure $\mathrm{CH}_{3} \mathrm{CN}\left(300-310 \Omega^{-1} \cdot \mathrm{cm}^{2} \cdot \mathrm{mol}^{-1}\right)$, decrease in aqueous acetonitrile solutions to 180-213 $\Omega^{-1} \cdot \mathrm{cm}^{2} \cdot \mathrm{mol}^{-1}$ with limiting values; slightly bigger than typical values for $1: 1$ electrolytes and much smaller than predicted for 1:2 electrolytes. In addition, the chlorido complexes, $[\mathrm{Cu}(\mathrm{L}) \mathrm{Cl}]^{+}$, in aqueous acetonitrile behave in a similar way, except their molar conductivity values were a little bit higher (Table 1).

On the other hand, the spectrophotometric titration of $[\mathrm{Cu}(\mathrm{L}) \mathrm{X}] \mathrm{ClO}_{4} / \mathrm{PF}_{6}$ dissolved in $\mathrm{CH}_{3} \mathrm{CN}$ with $\mathrm{H}_{2} \mathrm{O}$ showed a gradual shift of the band, which originally appeared at 645-770 $\mathrm{nm}$ region, to a shorter wavelength (ligand field strength of $\mathrm{H}_{2} \mathrm{O}$ ligand is stronger than $\left.\mathrm{CH}_{3} \mathrm{CN}\right)$. A typical example for the spectrophotometric titration of $\left[\mathrm{Cu}\left(\mathrm{L}^{1}\right) \mathrm{Cl}\right] \mathrm{PF}_{6}$ (1-Cl) is illustrated in Figure 3. These results can be interpreted in terms of the formation of the six-coordinate aqua species, $\left[\mathrm{Cu}(\mathrm{L})\left(\mathrm{H}_{2} \mathrm{O}\right) \mathrm{X}\right]^{+}$, which presumably exists in equilibrium with the $\left[\mathrm{Cu}(\mathrm{L})\left(\mathrm{H}_{2} \mathrm{O}\right)\right]^{2+}$ ion. The behavior of these complexes in $\mathrm{CH}_{3} \mathrm{CN}$ and $\mathrm{CH}_{3} \mathrm{CN}-\mathrm{H}_{2} \mathrm{O}$ solutions can be represented in Scheme 2. The extent of this equilibrium and the molar conductivity of the equilibrated solution depend on the $\mathrm{H}_{2} \mathrm{O} / \mathrm{CH}_{3} \mathrm{CN}$ volume ratios. A similar trend was observed in other $\mathrm{Cu}$ (II) chlorido and perchlorato complexes and recently in $\mathrm{Co}(\mathrm{II})$ complexes, $[\mathrm{Co}(\mathrm{L}) \mathrm{Cl}] \mathrm{ClO}_{4} / \mathrm{PF}_{6}(\mathrm{~L}=$ tripod tetraamine $)$ in similar media $[3,4]$.

In this scheme, we must emphasize on the fact that in pure $\mathrm{CH}_{3} \mathrm{CN}$ solution, while the complex ions $[\mathrm{Cu}(\mathrm{L}) \mathrm{Cl}]^{+}$do not react with $\mathrm{CH}_{3} \mathrm{CN}$, their corresponding perchlorato species, $\left[\mathrm{Cu}(\mathrm{L}) \mathrm{ClO}_{4}\right]^{+}$, react leading to the formation of $\left[\mathrm{Cu}(\mathrm{L})\left(\mathrm{CH}_{3} \mathrm{CN}\right)\right]^{2+}$ as it has been supported by the molar conductivity measurements, which were in agreement with 1:2 electrolyte in the latter case (Table 1). In aqueous acetonitrile solutions, the complexes $[\mathrm{Cu}(\mathrm{L}) \mathrm{X}] \mathrm{ClO}_{4} / \mathrm{PF}_{6}\left(\mathrm{X}=\mathrm{Cl}^{-}\right.$or $\left.\mathrm{ClO}_{4}{ }^{-}\right)$react instantaneously with $\mathrm{H}_{2} \mathrm{O}$ with color change, which was accompanied with a blue shift in the visible spectral region and increased molar conductivity values to the limit that is somewhere between 1:1 and 1:2 electrolytes as the water contents increases. Attempts made to estimate the $\mathrm{p} K_{\mathrm{a}}$ values of the coordinated $\mathrm{H}_{2} \mathrm{O}$ in the aqua species $\left[\mathrm{Cu}(\mathrm{L})\left(\mathrm{H}_{2} \mathrm{O}\right)\right]^{2+}$ were unsuccessful. Probably due to its presence in equilibrium with the corresponding hydroxido species $[\mathrm{Cu}(\mathrm{L})(\mathrm{OH})]^{+}$, which was proved to 
produce a dinuclear with bridged hydroxido derivatives (Scheme 2). This was supported by the isolation and structural characterization of $\left[\left(\mathrm{L}^{1}\right) \mathrm{Cu}_{2}(\mu-\mathrm{OH})\left(\mathrm{H}_{2} \mathrm{O}\right)(\mathrm{OAc})_{2} \mathrm{Cl}\right][51]$.

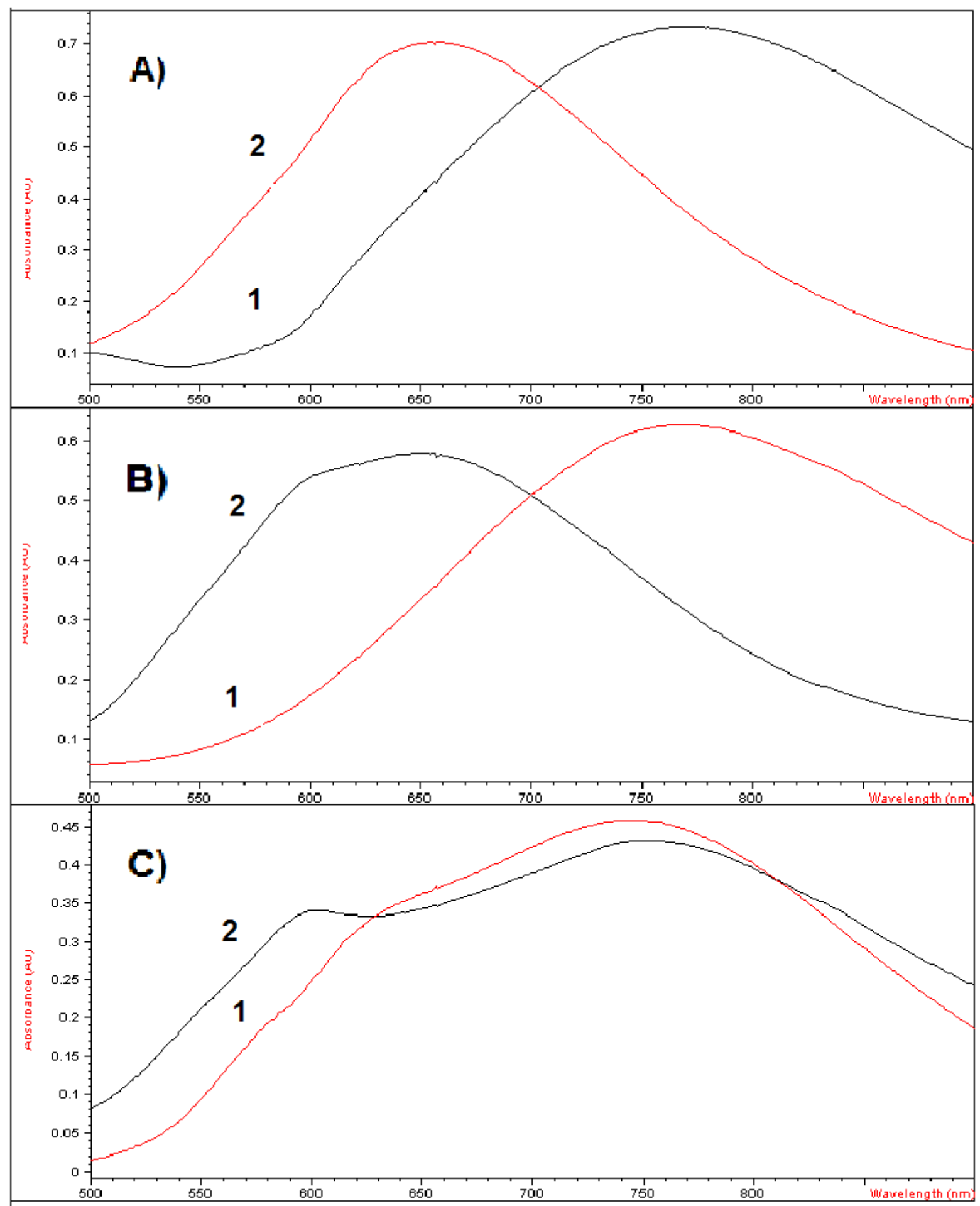

Figure 2. Visible spectra of (A) $1.14 \times 10^{-3} \mathrm{M}$ of $\left[\mathrm{Cu}\left(\mathrm{L}^{1}\right) \mathrm{Cl}\right] \mathrm{PF}_{6}(\mathbf{1}-\mathrm{Cl}),(\mathbf{B}) 8.87 \times 10^{-4} \mathrm{M}$ of $\left[\mathrm{Cu}\left(\mathrm{L}^{4}\right) \mathrm{Cl}\right] \mathrm{ClO}{ }_{4} \cdot \mathrm{H}_{2} \mathrm{O}(4-\mathrm{Cl})$, and $(\mathbf{C}) 8.00 \times 10^{-4} \mathrm{M}$ of $\left[\mathrm{Cu}\left(\mathrm{L}^{3}\right) \mathrm{ClO}_{4}\right] \mathrm{ClO}_{4}\left(3-\mathrm{ClO}_{4}\right)$ in $\mathrm{CH}_{3} \mathrm{CN}$ (1) and $\mathrm{CH}_{3} \mathrm{CN} / \mathrm{H}_{2} \mathrm{O}(1: 1$ by volume) (2) solutions. 


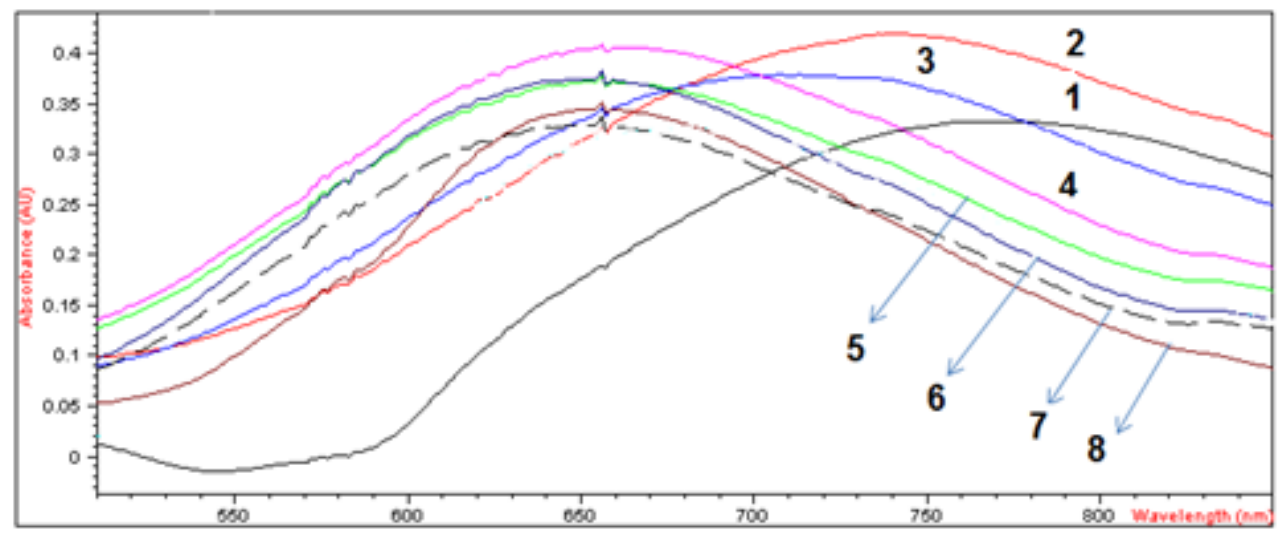

Figure 3. Spectrophotometric titration of $\left[\mathrm{Cu}\left(\mathrm{L}^{1}\right) \mathrm{Cl}\right] \mathrm{PF}_{6}(\mathbf{1}-\mathrm{Cl})\left(5.06 \times 10^{-4} \mathrm{M}\right)$ in aqueous acetonitrile solutions at room temperature. The $\mathrm{H}_{2} \mathrm{O} / \mathrm{CH}_{3} \mathrm{CN}$ volume ratios were as follows: (1) 0/10, (2) 0.3/9.7, (3) 0.6/9.4 (4) 1.5/8.5, (5) 2.0/8.0, (6) 2.6/7.4, (7) 3.3/6.7, and (8) 4.0/6.0.

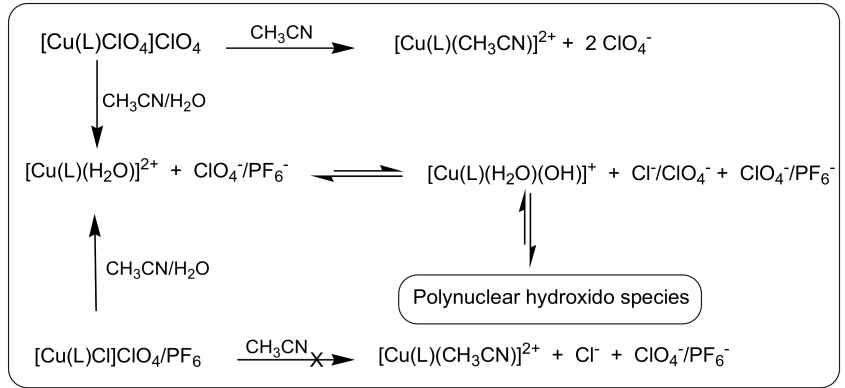

Scheme 2. Proposed solvolysis and aquation reactions of $[\mathrm{Cu}(\mathrm{L}) \mathrm{X}] \mathrm{ClO}_{4} / \mathrm{PF}_{6}$ complexes $\left(\mathrm{X}=\mathrm{Cl}^{-}\right.$or $\left.\mathrm{ClO}_{4}{ }^{-} ; \mathrm{L}=\mathrm{L}^{1}-\mathrm{L}^{5}\right)$ in acetonitrile and aqueous acetonitrile solutions.

\subsection{DNA Cleavage Studies}

\subsubsection{Concentration Dependence}

The cleavage activity of complexes $\left[\mathrm{Cu}(\mathrm{L})\left(\mathrm{ClO}_{4}\right) / \mathrm{Cl}\right] \mathrm{ClO}_{4} / \mathrm{PF}_{6}$ was investigated towards plasmid DNA pBR322 at near-physiological conditions (10 mM MOPS (3-morpholino propane-1-sulfonic acid) buffer $\mathrm{pH} 7.4,37^{\circ} \mathrm{C}$ ). The reactivity was monitored at $0,60,120$, 180, 300, 420, and $540 \mu \mathrm{M}$ complex concentrations after $2 \mathrm{~h}$ of incubation (Figure 4 and Figure S10), by quantifying the conversion of supercoiled plasmid DNA (form I) into open circular (form II) and linear DNA (form III). These figures demonstrate that the nucleolytic activity of the investigated complexes is decreasing in the order: $1-\mathrm{Cl} \approx 1-\mathrm{ClO}_{4}>3-\mathrm{ClO}_{4}$ $\geq 2-\mathrm{ClO}_{4}$, with no discernible cleavage activity by $4-\mathrm{Cl}, 5-\mathrm{Cl}$, and $6-\mathrm{ClO}_{4}$ when compared with noncatalyzed plasmid DNA cleavage (background control).

A comparison between $\left[\mathrm{Cu}\left(\mathrm{L}^{1}\right)\left(\mathrm{ClO}_{4}\right)\right] \mathrm{ClO}_{4}, \mathbf{1}-\mathrm{ClO}_{4}$, and $\left[\mathrm{Cu}\left(\mathrm{L}^{1}\right) \mathrm{Cl}\right] \mathrm{PF}_{6}, \mathbf{1}-\mathrm{Cl}$ shows that the identity of the coordinated anionic ligand $\left(\mathrm{ClO}_{4}{ }^{-} \mathrm{vs}\right.$. $\mathrm{Cl}^{-}$in the inner coordination sphere) and the counter ion $\left(\mathrm{ClO}_{4}{ }^{-}\right.$vs. $\left.\mathrm{PF}_{6}{ }^{-}\right)$of the complexes have no influence on the cleavage activity. This is a common observation, which might be explained by the formation of the same reactive species, $\left[\mathrm{Cu}(\mathrm{L})\left(\mathrm{H}_{2} \mathrm{O}\right)\right]^{2+}$ in aqueous solutions in both complexes $1-\mathrm{ClO}_{4}$ and 1-Cl [3]. As expected, in comparison with the complexes, the corresponding ligands did not show any significant DNA cleavage activity, even at $540 \mu \mathrm{M}$ concentration (Figure S11).

\subsubsection{Kinetics of DNA Cleavage}

The conversion of DNA form I to form II was analyzed kinetically for the complexes 1$\mathrm{ClO}_{4}-3-\mathrm{ClO}_{4}$ and $\mathbf{1 - C l}$ at concentrations of $0,60,120,180,300,420$, and $540 \mu \mathrm{M}$ after 10, 20, 40, 60, 90, and $120 \mathrm{~min}$ incubation time (Figure 5). Rates of reactions were performed under pseudo-first-order Michaelis-Menten kinetics, and the data were fitted to an exponential decay function (Equation (1), experimental section). The kinetic parameters, i.e., the 
catalytic rate constant, $k_{\mathrm{cat}}$, and the affinity constant, $K_{\mathrm{M}}$, collected in Table 2, were derived from Lineweaver Burk plots $\left(1 / k_{\text {obs }}\right.$ vs. $\left.1 /[\mathrm{Cu}]\right)$. The values of $k_{\text {cat }}$ decrease in the order: $1-\mathrm{Cl} \approx 1-\mathrm{ClO}_{4}>3-\mathrm{ClO}_{4} \geq 2-\mathrm{ClO}_{4}$, corroborating the activity trend of the complexes based on concentration-dependent DNA cleavage data (vide supra). For complexes 1- $\mathrm{ClO}_{4}-\mathbf{3 -}$ $\mathrm{ClO}_{4}$ and 1- $\mathrm{Cl}$ values in the range of $0.1-0.8 \mathrm{~h}^{-1}$ were obtained. Rate enhancements over the uncatalyzed cleavage reaction $\left(k=3.6 \times 10^{-8} \mathrm{~h}^{-1}\right)$ [1] were in the range of 20 million for complexes 1, but only around 2-4 million for the other tested complexes. This means that substituted pyridyl arms in the $\mathrm{Cu}$ (II)-piperazine complexes did not result in any significant higher reactivity compared to the unsubstituted pyridyl piperazine ligand system (complexes $\mathbf{1}$ with $\mathrm{L}^{1}$ ).

(a)

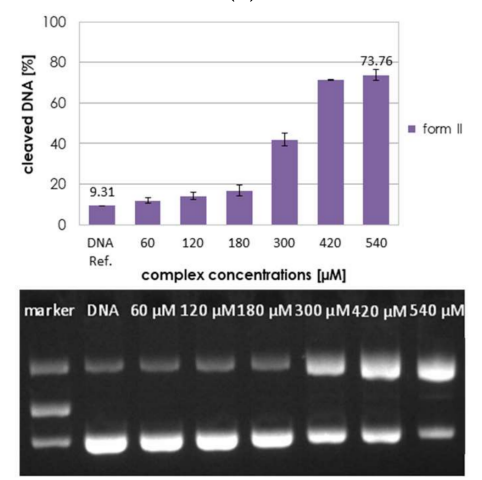

(b)

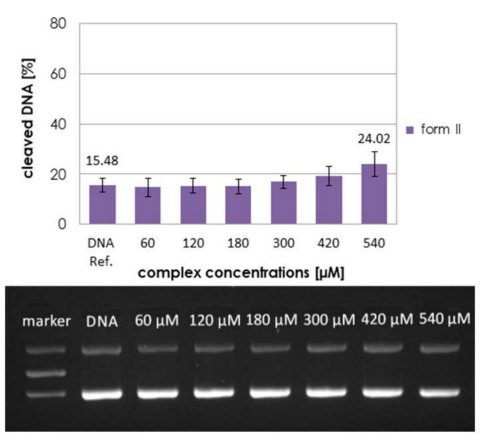

(c)

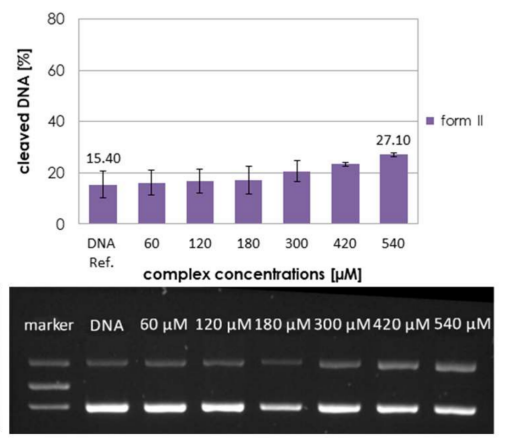

Figure 4. Cleavage of pBR322 plasmid DNA $(0.025 \mu \mathrm{g} / \mu \mathrm{L})$ into form II by the complexes $\left[\mathrm{Cu}(\mathrm{L})\left(\mathrm{ClO}_{4}\right)\right] \mathrm{ClO}_{4}$ at concentra-

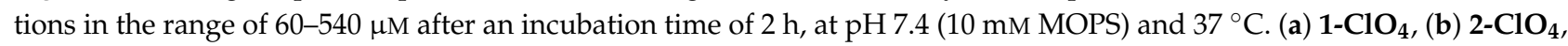
and (c) 3-- $\mathrm{ClO}_{4}$, Lane 1: marker and Lane 2: control without added complex.

(a)

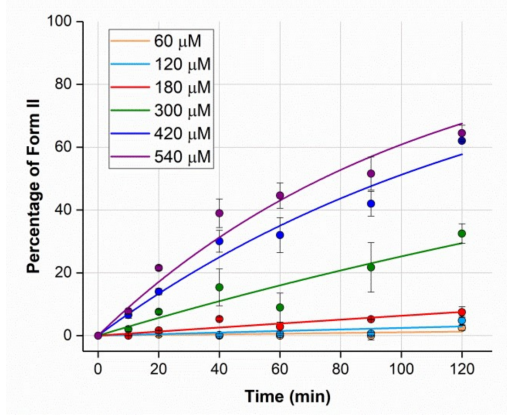

(c)

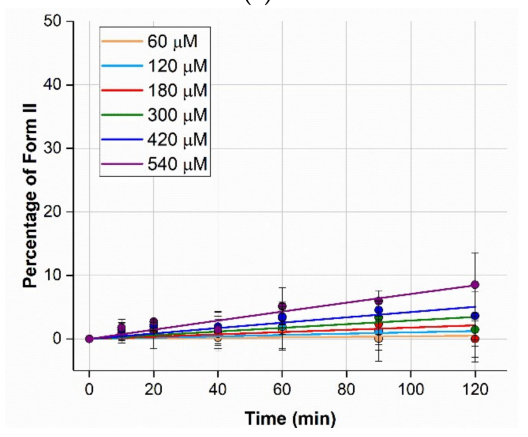

(b)

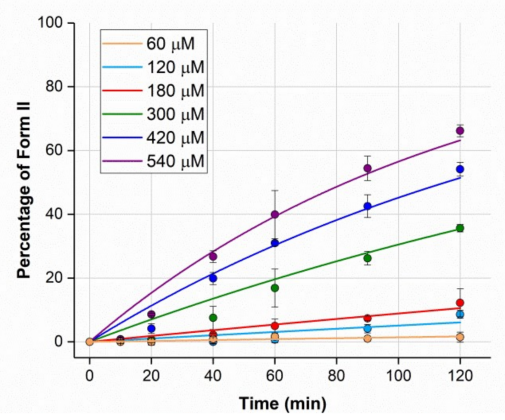

(d)

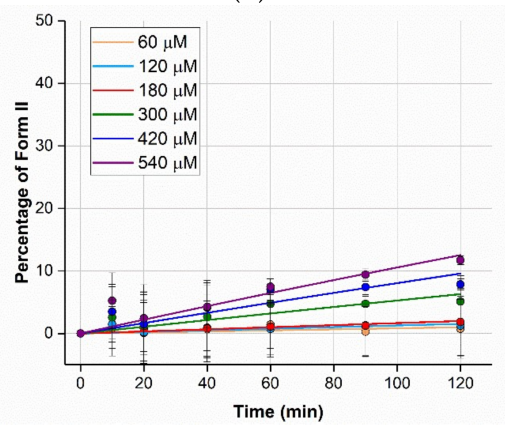

Figure 5. Plot of the percentage of form II vs. incubation time for the cleavage of pBR322 plasmid DNA $(0.025 \mu \mathrm{g} / \mu \mathrm{L}) \mathrm{by}$

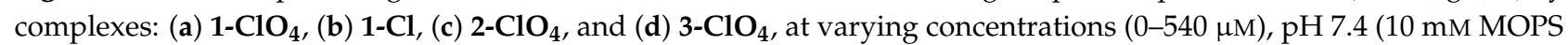
buffer), and $37^{\circ} \mathrm{C}$. The plots show the fitted function (Equation (1)) used to determine the observed rate constant, $k_{\mathrm{obs}}$ at each complex concentration. 
Table 2. Pseudo-first-order Michaelis-Menten kinetic data for the cleavage of pBR322 plasmid DNA $(0.025 \mu \mathrm{g} / \mu \mathrm{L})$ by the complexes 1- $\mathrm{ClO}_{4}-\mathbf{3}-\mathrm{ClO}_{4}$ and $\mathbf{1 - C l}$ at $37^{\circ} \mathrm{C}$ and $\mathrm{pH} 7.4$.

\begin{tabular}{|c|c|c|c|c|c|c|}
\hline Complex & $\mathbf{c}(\mu \mathbf{M})$ & $k_{\mathrm{obs}}\left(\min ^{-1}\right)$ & $k_{\text {cat }}\left(\mathrm{h}^{-1}\right)$ & $K_{M}(\mathrm{M})$ & $k_{\mathrm{cat}} / K_{\mathrm{M}}$ & $\begin{array}{c}\text { Rate } \\
\text { Enhancement }\end{array}$ \\
\hline \multirow[t]{6}{*}{$1-\mathrm{ClO}_{4}$} & 60 & $2.65 \times 10^{-5}$ & $7.79 \times 10^{-1}$ & $5.03 \times 10^{-4}$ & $5.58 \times 10^{6(a)}$ & $2.2 \times 10^{7}$ \\
\hline & 120 & $3.05 \times 10^{-5}$ & & & & \\
\hline & 180 & $3.91 \times 10^{-5}$ & & & & \\
\hline & 300 & $8.99 \times 10^{-5}$ & & & & \\
\hline & 420 & $2.02 \times 10^{-4}$ & & & & \\
\hline & 540 & $2.47 \times 10^{-4}$ & & & & \\
\hline \multirow[t]{6}{*}{ 1-Cl } & 60 & $2.44 \times 10^{-5}$ & $8.23 \times 10^{-1}$ & $5.89 \times 10^{-4}$ & $5.03 \times 10^{6}$ & $2.3 \times 10^{7}$ \\
\hline & 120 & $2.62 \times 10^{-5}$ & & & & \\
\hline & 180 & $4.11 \times 10^{-5}$ & & & & \\
\hline & 300 & $9.36 \times 10^{-5}$ & & & & \\
\hline & 420 & $1.63 \times 10^{-4}$ & & & & \\
\hline & 540 & $2.34 \times 10^{-4}$ & & & & \\
\hline \multirow[t]{6}{*}{$2-\mathrm{ClO}_{4}$} & 60 & $1.62 \times 10^{-5}$ & $9.75 \times 10^{-2}$ & $4.41 \times 10^{-5}$ & $7.95 \times 10^{6}$ & $2.7 \times 10^{6}$ \\
\hline & 120 & $1.86 \times 10^{-5}$ & & & & \\
\hline & 180 & $2.02 \times 10^{-5}$ & & & & \\
\hline & 300 & $2.25 \times 10^{-5}$ & & & & \\
\hline & 420 & $2.58 \times 10^{-5}$ & & & & \\
\hline & 540 & $2.81 \times 10^{-5}$ & & & & \\
\hline \multirow[t]{6}{*}{$3-\mathrm{ClO}_{4}$} & 60 & $1.84 \times 10^{-5}$ & $1.55 \times 10^{-1}$ & $9.72 \times 10^{-5}$ & $5.72 \times 10^{6}$ & $4.3 \times 10^{6}$ \\
\hline & 120 & $1.96 \times 10^{-5}$ & & & & \\
\hline & 180 & $2.05 \times 10^{-5}$ & & & & \\
\hline & 300 & $3.44 \times 10^{-5}$ & & & & \\
\hline & 420 & $4.57 \times 10^{-5}$ & & & & \\
\hline & 540 & $4.77 \times 10^{-5}$ & & & & \\
\hline
\end{tabular}

(a) The previously found values were $k_{\text {cat }}=8.89 \times 10^{-1} \mathrm{~h}^{-1}$ and $K_{\mathrm{M}}=3.35 \times 10^{-4} \mathrm{M}$ at pH 7.0 with pUC19 DNA (Reference [6]).

(b) Uncatalyzed DNA cleavage reaction $k=3.6 \times 10^{-8} \mathrm{~h}^{-1}$ at $37^{\circ} \mathrm{C}$ and $\mathrm{pH} 7.0$ (Reference [1]).

\subsection{BNPP Assay}

In order to further investigate the hydrolytic cleavage activity, BNPP (bis(p-nitrophenyl) phosphate) was used as a substrate to mimic the phosphate ester backbone of DNA [52]. Through cleavage of BNPP, the released $p$-nitrophenolate anion was monitored by UV-VIS spectroscopy, following the absorption increase at $400 \mathrm{~nm}$ [53]. As a positive control, phosphodiesterase was incubated for $2 \mathrm{~h}$ with BNPP (Figure S12). None of the studied complexes $\left(1-\mathrm{ClO}_{4}-3-\mathrm{ClO}_{4}, 6-\mathrm{ClO}_{4}, \mathbf{1}-\mathrm{Cl}, 4-\mathrm{Cl}\right.$, and $\left.5-\mathrm{Cl}\right)$ was able to cleave BNPP measurably within $2 \mathrm{~h}$ (Figure S13), however, while $\mathbf{2}-\mathrm{ClO}_{4}$ showed significant cleavage activity after $48 \mathrm{~h}$ incubation, some cleavage was observed for $3-\mathrm{ClO}_{4}$ and very little for $\mathbf{1}-\mathrm{Cl}$ (reactivity decreases: 2- $\mathrm{ClO}_{4}>3-\mathrm{ClO}_{4}>\mathbf{1 - C l}$ ) (Figure 6). These effects are more pronounced after $96 \mathrm{~h}$ (Figures S13 and S14 ). Thus, a hydrolytic cleavage mechanism can now be assumed for complexes $\mathbf{2}$ and 3. 


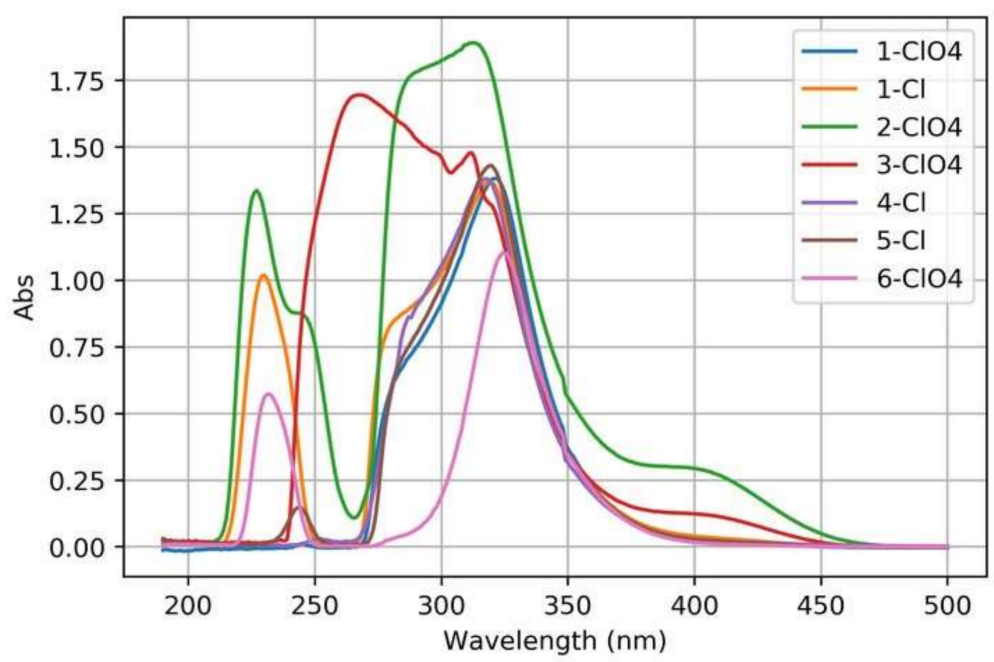

Figure 6. UV-VIS spectra of bis(p-nitrophenyl)phosphate (BNPP) $(270 \mu \mathrm{M})$ in MOPS buffer $(10 \mathrm{mM}$, $\mathrm{pH} 7.4)$ in the presence of $\mathrm{Cu}(\mathrm{II})$ complexes $(540 \mu \mathrm{M})$ after $48 \mathrm{~h}$ incubation at $37^{\circ} \mathrm{C}$.

\subsection{Reactive Oxygen Species (ROS)}

In order to reveal the mechanistic pathway of the DNA cleavage (hydrolytic vs. redox) by the complexes under investigation $\mathbf{1}-\mathrm{ClO}_{4}, \mathbf{2}-\mathbf{C l O}_{4}$, and $\mathbf{3}-\mathrm{ClO}_{4}(540 \mu \mathrm{M})$, it was necessary to study the role of redox species on the DNA cleavage process. This was done using quenchers for reactive oxygen species (DMSO for hydroxyl radicals, KI for peroxide, and $\mathrm{NaN}_{3}$ for reactive singlet oxygen). The results are illustrated in Figure 7. These results indicate that DMSO did not reduce the cleavage activity in any of the complexes, which exclude the hydroxyl radicals as reactive species. The DNA cleavage activity was slightly affected by $\mathrm{NaN}_{3}$ scavenger, which may reflect the minor contribution of singlet oxygen in the DNA cleavage mechanism. However, for some of the complexes, hydrogen peroxide was identified as the only ROS involved in DNA cleavage (Figure 7). Since such a quenching assay is sensitive regarding specific reaction conditions, the outcome of this experiment was verified exemplarily for $\mathbf{1}-\mathrm{ClO}_{4}$ with a fluorescence assay, where hydroxyl radicals and hydrogen peroxide are supposed to activate fluorogenic compounds (Figure S15) [54]. This test was positive for hydrogen peroxide and negative for hydroxyl radicals (singlet oxygen could not be tested).

Through inspection of the BNPP cleavage and ROS scavenging experiments one can get some insights into the mechanistic pathway of DNA cleavage by the title complexes. The DNA cleavage activity of $\mathbf{2}-\mathrm{ClO}_{4}$, which efficiently cleaved BNPP and was slightly reduced when quenchers were added, leads us to exclude the oxidative mechanism and support the hydrolysis as the dominant mechanism. The same applies also for $3-\mathrm{ClO}_{4}$ even though the situation is less clear and both mechanisms might contribute to the activity. In addition, it should be considered that BNPP and DNA are only conditionally comparable, i.e., BNPP is a DNA mimic only with respect to the phosphate diester, other properties like the secondary structure cannot be represented by BNPP. In case of $\mathbf{1 - C 1 O _ { 4 }}$, which was much less active for BNPP cleavage, an oxidative cleavage mechanism with hydrogen peroxide as a dominant ROS can be considered, since DNA cleavage was almost completely reduced in the presence of KI. This mechanistic detail had not been revealed in previous work [6]. Since no reducing agent was present for DNA cleavage, and the buffer improbably represents reducing agent (e.g., MOPS is inefficiently oxidized by $\mathrm{H}_{2} \mathrm{O}_{2}$ [55]), the generation of $\mathrm{ROS}$ is not obvious, since they are commonly formed by reduction of $\mathrm{Cu}$ (II) and then reaction of $\mathrm{Cu}(\mathrm{I})$ with $\mathrm{O}_{2}$. Thus, self-activated DNA cleavage is to be assumed. This usually implies the ligand scaffold as the reducing species $[10,56]$, however, also a redox reaction with the DNA itself (especially the guanine nucleobase) is conceivable [9]. 
(a)

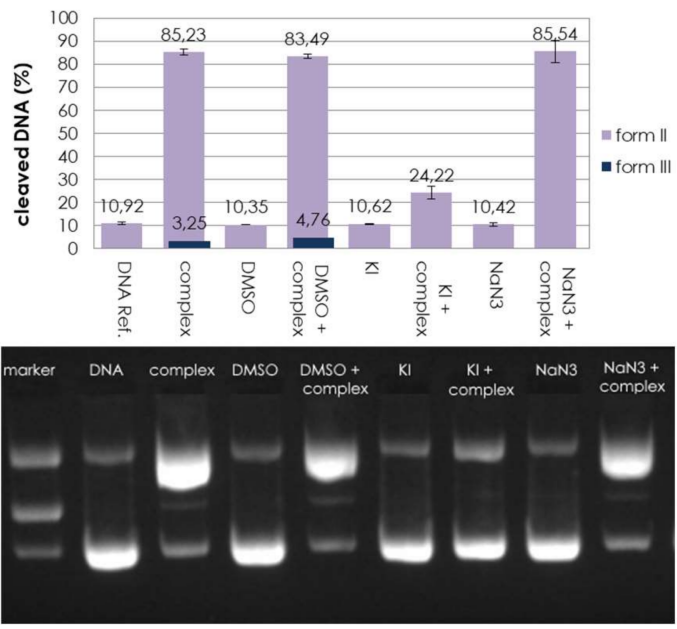

(b)
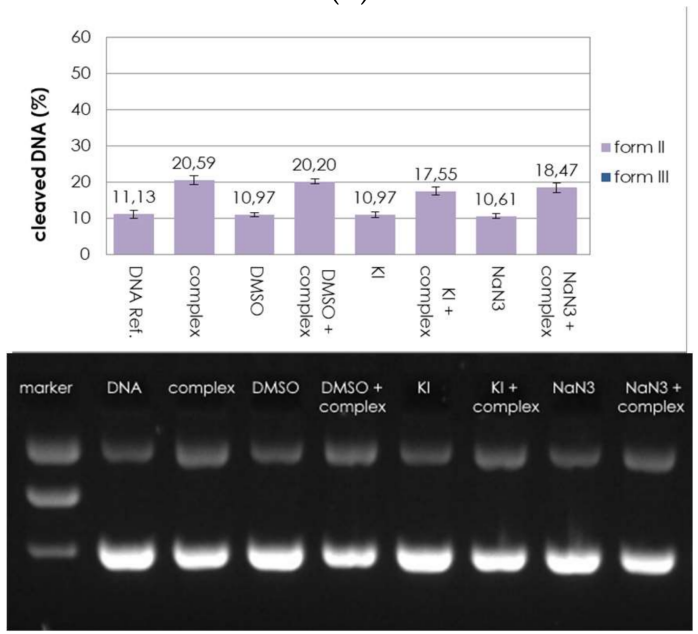

(c)

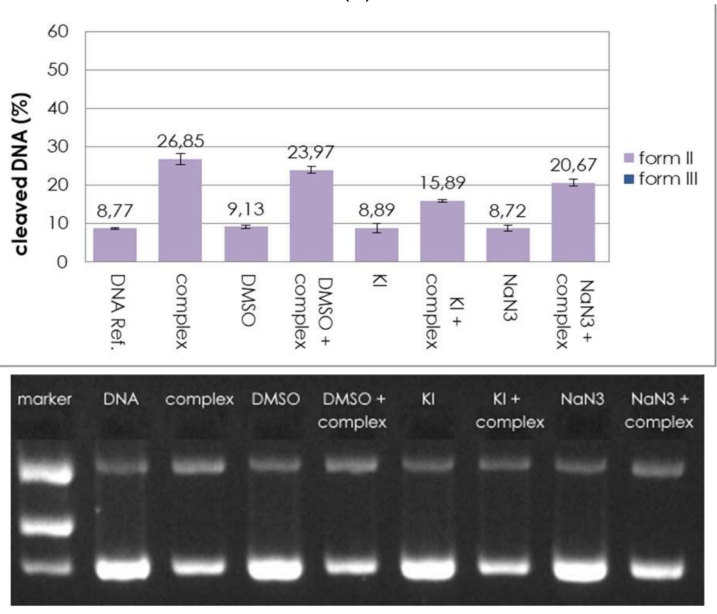

Figure 7. Cleavage of pBR322 plasmid DNA $(0.025 \mu \mathrm{g} / \mu \mathrm{L})$ by complexes $(540 \mu \mathrm{M})$ : (a) $\mathbf{1}-\mathrm{ClO}_{4}$, (b) $\mathbf{2}-\mathrm{ClO}_{4}$, and (c) $\mathbf{3}-\mathrm{ClO}_{4}$ after an incubation time of $2 \mathrm{~h}$ at $37^{\circ} \mathrm{C}$ in the presence and absence of ROS scavengers $(0.4 \mathrm{M} \mathrm{DMSO}, 500 \mu \mathrm{M} \mathrm{KI}, 500 \mu \mathrm{M}$ $\mathrm{NaN}_{3}$ ) in MOPS buffer (10 mM, pH 7.4).

Thus, it was demonstrated that under pseudo-first-order Michaelis-Menten conditions, the DNA cleavage activity by the chlorido or perchlorato complexes 1-6 is sensitive to the ligand framework, which have pronounced influence not only on the rate of reactions but also on the preferred reaction mechanism; the catalytic rate constant, $k_{\text {cat }}$, decreases in the series $\mathbf{1}>\mathbf{3} \geq \mathbf{2}$, whereas complexes 4-6 were found inactive. As it can be derived from the molecular structures of the inactive complexes 4-Cl and 5-Cl (Figure 1), the methoxy substituents at the pyridine moieties might hinder and/or suppress the intercalation of the complexes with DNA and hence their DNA cleavage activity. Previous results showed that increasing number of methoxy substituents at the pyridine moieties of pyridyl-derived ligand systems improves the hydrolytic DNA cleavage activity, but this trend could not be confirmed with the current ligands [3,11]. In addition, the molecular structure of complex 6- $\mathrm{ClO}_{4}$, which does not show DNA cleavage activity, indicates that the $\mathrm{Cu}$ (II) center is sterically shielded [47] and hence not easily accessible for neither hydrolytic (cleavage of the phosphate ester backbone) nor oxidative (reaction with $\mathrm{O}_{2}$ for ROS generation) DNA cleavage reactions.

In this study, results of BNPP and ROS quenching examinations indicate that the most reactive complexes $1-\mathrm{ClO}_{4} / \mathrm{Cl}$ seem to favor an oxidative pathway mechanism, whereas 2 and 3 dominantly cleave DNA in a hydrolytic fashion. Rate enhancements are 5-10 times higher for complexes $\mathbf{1}$ than for $\mathbf{2}$ and 3. Among the hydrolytically cleaving nucleases, 
3- $\mathrm{ClO}_{4}$ can intercalate into DNA more easily in comparison to $2-\mathrm{ClO}_{4}$ due to the more extended quinoline-derived ligand system of $\mathbf{L}^{3}$ compared to the pyridine-derived ligand of $\mathrm{L}^{2}$ and this explains the reactivity trend $3-\mathrm{ClO}_{4}>2-\mathrm{ClO}_{4}$.

\subsection{Cytotoxicity Studies}

Cytotoxicity of the $\mathrm{Cu}$ (II) complexes was analyzed by means of the MTT assay in vitro in human ovarian carcinoma cells A2780 and human fibroblasts. The cells were incubated with different concentrations of the compounds $(0.0096,0.096,0.96,9.6,96$, and $115 \mu \mathrm{M})$. Results of the MTT assay in A2780 cells and the calculated $\mathrm{IC}_{50}$ values are depicted in Figure 8, and other results in human fibroblast cells are shown in Figure S16. The IC 50 values for the two studied cell lines A2780 and fibroblasts are tabulated in Table 3. Inspection of the data in Table 3 reveals that the $\mathrm{IC}_{50}$ values of $30-40 \mu \mathrm{M}$ were found for $\mathbf{1}-\mathrm{ClO}_{4}, \mathbf{3}-\mathrm{ClO}_{4}$, and $5-\mathrm{Cl}$, whereas the other complexes did not show cytotoxic activity. Even though $\mathrm{IC}_{50}$ values are not that low for complexes $\mathbf{1}-\mathrm{ClO}_{4}, 3-\mathrm{ClO}_{4}$, and $5-\mathrm{Cl}$, i.e., these compounds are not that cytotoxic, an important finding is that in fibroblasts, these values were much higher for $1-\mathrm{ClO}_{4}(66.3 \mu \mathrm{M})$ and $5-\mathrm{Cl}(90.7 \mu \mathrm{M})$. For $3-\mathrm{ClO}_{4}$ complex, even no effect on the fibroblasts was found.

(a)

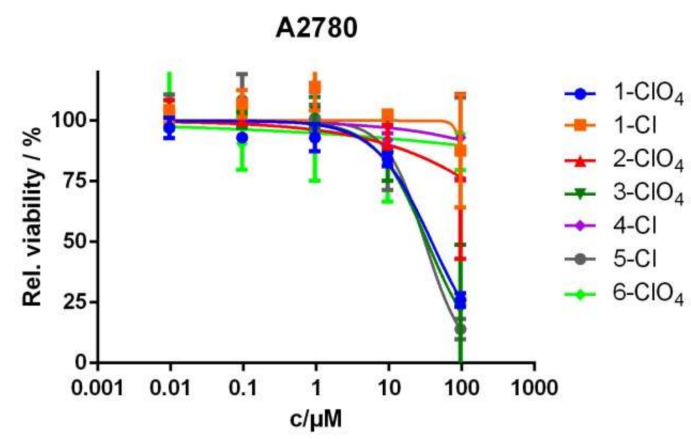

(b)

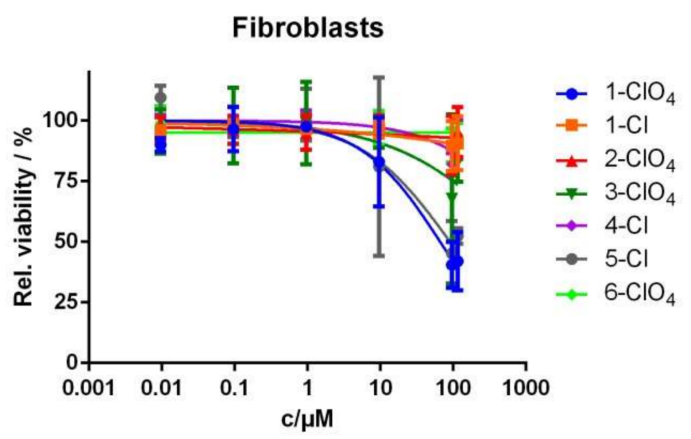

Figure 8. Results of the 3-(4,5-dimethylthiazol-2-yl)-2,5-diphenyltetrazolium bromide (MTT) assay in A2780 cells (a) and fibroblasts (b). Corresponding bar diagrams can be found in the Supplementary (Figure S16).

Table 3. The IC50 values (95\% confidence interval) in A2780 and fibroblasts cells.

\begin{tabular}{ccc}
\hline Complex & IC50 Value $(\mu \mathrm{M})$ in A2780 Cells & IC50 Value $(\mu \mathrm{M})$ in Fibroblasts \\
\hline $\mathbf{1 - C l O}$ & $38.7(27.7-53.9)$ & $66.4(44.1-99.1)$ \\
\hline $1-\mathrm{Cl}$ & $>100$ & $>100$ \\
\hline $\mathbf{2}-\mathrm{ClO}_{4}$ & $>100$ & $>100$ \\
\hline $3-\mathrm{ClO}_{4}$ & $33.6(18.1-62.6)$ & $>100$ \\
\hline $\mathbf{4 - C l}$ & $>100$ & $>100$ \\
\hline $\mathbf{5 - C l}$ & $31.2(18.1-53.9)$ & $90.7(51.0-161.5)$ \\
\hline $\mathbf{6}-\mathrm{ClO}_{4}$ & $>100$ & $>100$ \\
\hline
\end{tabular}

Ligand $\mathrm{L}^{3}$, which shows slight DNA cleavage, was the only ligand to exhibit cytotoxic ity-but only in the cancer cells $(77.3 \mu \mathrm{M}$, in fibroblasts $>100 \mu \mathrm{M})$. This suggests that the ligand might also be involved in the high cytotoxicity of complex 3-ClO 4 in A2780 cells. Cell uptake of metal complexes, which is an important prerequisite for their cytotoxicity, is usually dependent on their lipophilicity [57], and the quinoline-based ligand $\mathrm{L}^{3}$ is supposed to be more lipophilic than the pyridine-based ligands. Selectivity for certain cell lines has been observed before for quinoline-derived compounds [58]. 


\section{Materials and Methods}

\subsection{General}

Piperazine and the hydrochloride salts of 2-chloromethylquinoline, 2-chloromethylpy ridine, 3,4-dimethoxy-2-chloromethylpyridine, and 3,5-dimethyl-4-methoxy-2-chloromethy lpyridine were purchased from TCI-America. Further, 6-Methyl-2-pyridinemethanol was purchased from Alfa Aesar, whereas 2-vinylpyridine was obtained from Aldrich Chem. Comp., and purified by column chromatography using alumina eluted with $\mathrm{Et}_{2} \mathrm{O}$ before use. All other reagents were used without further purification. Infrared spectra were recorded on a Cary 630 (ATR-IR) spectrometer. NMR $\left({ }^{1} \mathrm{H}\right.$ and $\left.{ }^{13} \mathrm{C}\right)$ spectra were obtained at room temperature on a Varian $400 \mathrm{NMR}$ spectrometer operating at $400 \mathrm{MHz}\left({ }^{1} \mathrm{H}\right)$ and 100 $\mathrm{MHz}\left({ }^{13} \mathrm{C}\right)$. Moreover, ${ }^{1} \mathrm{H}$ and ${ }^{13} \mathrm{C}$ NMR chemical shifts $(\delta)$ are reported in ppm and were referenced internally to residual solvent resonances (DMSO- $d_{6}: \delta_{\mathrm{H}}=2.49, \delta_{\mathrm{C}}=39.4 \mathrm{ppm}$ ). ESI-MS were measured on LC-MS Varian Saturn 2200 Spectrometer and electronic spectra were recorded using an Agilent 8453 HP diode UV-VIS spectrophotometer. Elemental analyses were carried out by the Atlantic Microlab, Norcross, GA, USA.

The molar conductivity of a solution sample was determined from $\Lambda_{\mathrm{M}}=\left(1.0 \times 10^{3} \mathrm{~K}\right) /[\mathrm{Cu}]$, where $\mathrm{k}=$ specific conductance and $[\mathrm{Cu}]$ is the molar concentration of the complex. The measurements were performed using Mettler Toledo SevenEasy conductometer and calibrated with $1413 \mu \mathrm{S} / \mathrm{cm}$ conductivity standard.

Caution: Salts of perchlorate and their metal complexes are potentially explosive and should be handled with great care and in small quantities.

\subsection{Syntheses}

In brief, 6-methyl-2-pyridinemethanol was converted into 6-methyl-2-chloromethylpy ridine hydrochloride with the aid of $\mathrm{SOCl}_{2}$ in $\mathrm{CHCl}_{3}$, followed by recrystallization from ethanol. Further, 1,4-bis[(2-pyridinyl)methyl]piperazine $\left(\mathrm{L}^{1}\right)$ and 1,4-bis[(2-pyridinyl)-(2ethyl)]piperazine $\left(\mathrm{L}^{6}\right)$ were prepared according to the published literature $[6,47]$. The compounds $\mathrm{L}^{2}-\mathrm{L}^{5}$ were synthesized as follows:

\subsubsection{1,4-Bis[(6-methyl)-(2-pyridinyl)methyl]piperazine $\left(\mathrm{L}^{2} \cdot \frac{1}{4} \mathrm{H}_{2} \mathrm{O}\right)$}

To a mixture containing piperazine $(0.431 \mathrm{~g}, 5 \mathrm{mmol})$ and 6-methyl-2-chloromethylpyri dine hydrochloride $(1.78 \mathrm{~g}, 10 \mathrm{mmol})$ suspended in anhydrous $\mathrm{CH}_{3} \mathrm{CN}(40 \mathrm{~mL})$, excess $\mathrm{K}_{2} \mathrm{CO}_{3}(2.08 \mathrm{~g}, 15 \mathrm{mmol})$ was added. Nitrogen gas was purged through the mixture, which was magnetically stirred under gentle reflux for 3 days, during which color turned bright yellow. The resulting mixture was cooled in the refrigerator and filtered off to remove $\mathrm{KCl}$ and unreacted $\mathrm{K}_{2} \mathrm{CO}_{3}$. The solvent was removed with a rotary evaporator under reduced pressure and the resulting crude product was recrystallized from $\mathrm{Et}_{2} \mathrm{O}$ with aid of activated charcoal. The solvent was evaporated and the desired product was obtained as a light-yellow solid upon drying in a desiccator containing $\mathrm{P}_{4} \mathrm{O}_{10}$ under vacuum (overall yield: 1.25 g, $84 \%$ ). m.p. $=108-112{ }^{\circ} \mathrm{C}$. Found: C, 71.56; H, 8.10; N, $18.26 \%$. Calcd for $\mathrm{C}_{18} \mathrm{H}_{24} \mathrm{~N}_{4} \cdot \frac{1}{4} \mathrm{H}_{2} \mathrm{O}(\mathrm{MM}=296.410 \mathrm{~g} / \mathrm{mol}): \mathrm{C}, 71.85 ; \mathrm{H}, 8.21 ; \mathrm{N}, 18.62 \%$. Selected IR (ATR-IR, $\mathrm{cm}^{-1}$ ): 2953 (vw), $2919(\mathrm{vw}), 2881(\mathrm{vw}), 2802(\mathrm{~m})$ (aliphatic C-H stretching), 1592 (s), 1576 (s), $1458(\mathrm{~s}), 1446$ (s) (C=C, C=N stretching of pyridyl rings), 1009 (s), $933(\mathrm{~m}), 840(\mathrm{~s}), 788$ (vs), 757 (s) (C-H out of plane bending). ESI-MS in MeOH: $\mathrm{m} / z=297.206$ (100\%) (Calcd for $[\mathrm{M}+\mathrm{H}]^{+}=297.208$ ) (Figure S5). ${ }^{1} \mathrm{H}$ NMR (DMSO- $d_{6}, 400 \mathrm{MHz}, \delta$ in ppm): $\delta=2.42$ $\left(6 \mathrm{H}, \mathrm{s},-\mathrm{CH}_{3}\right), 3.32\left(\mathrm{~s},-\mathrm{CH}_{2}-\mathrm{pipz}\right), 3.53\left(\mathrm{~s}, 2 \mathrm{H},-\mathrm{CH}_{2}\right.$ of substituted py), 7.08, 7.10 and 7.19 , 7.21 (d, 1H, each corresponds to one CH-py), 7.60, 7.62, 7.64 (t, 1H, CH-py) (Figure S1). ${ }^{13} \mathrm{C}$ NMR: (DMSO- $\left.d_{6}, 100 \mathrm{MHz}\right) \delta=23.92\left(\mathrm{CH}_{3}\right.$-py), 52.82, $63.78\left(\mathrm{CH}_{2}\right.$-py and $\mathrm{CH}_{2}$-pipz), $119.49,121.20,136.61,156.92,157.70$ (pyridyl carbons) (Figure S1).

\subsubsection{1,4-Bis[(2-quinolyl)methyl]piperazine $\left(\mathrm{L}^{3} \cdot \frac{1}{4} \mathrm{H}_{2} \mathrm{O}\right)$}

To a mixture containing piperazine $(0.431 \mathrm{~g}, 5 \mathrm{mmol})$ and 2-chloromethylquinoline hydrochloride ( $2.15 \mathrm{~g}$. $10 \mathrm{mmol})$ suspended in anhydrous THF $(40 \mathrm{~mL})$, an excess of anhydrous $\mathrm{K}_{2} \mathrm{CO}_{3}(2.074 \mathrm{~g}, 15 \mathrm{mmol})$ was added. Nitrogen gas was purged through the 
mixture, which was magnetically stirred under gentle reflux for 3 days, during which color turned to orange-brown. The resulting mixture was cooled in the refrigerator and filtered off to remove $\mathrm{KCl}$ and unreacted $\mathrm{K}_{2} \mathrm{CO}_{3}$, and the solvent was removed with a rotary evaporator under reduced pressure. The resulting residue was extracted with $\mathrm{CH}_{2} \mathrm{Cl}_{2}$ $(15 \mathrm{~mL} \times 3)$ in $10 \% \mathrm{NaOH}(20 \mathrm{~mL})$ and saturated $\mathrm{NaCl}(20 \mathrm{~mL})$, and this was then washed with $\mathrm{H}_{2} \mathrm{O}(20 \mathrm{~mL} \times 3)$. The combined organic layers were collected and solvent was evaporated by rotary evaporator. The resulting solid was recrystallized from benzene with the aid of activated charcoal, followed by the addition of anhydrous $\mathrm{MgSO}_{4}$. The desired product was obtained as off-white to pale yellow color and dried in a desiccator containing $\mathrm{P}_{4} \mathrm{O}_{10}$ under vacuum (yield 0.90 g, 46\%). m.p. $=154-158{ }^{\circ} \mathrm{C}$. Found: $\mathrm{C}, 61.13 ; \mathrm{H}, 7.17 ; \mathrm{N}$, $14.28 \%$. Calcd for $\mathrm{C}_{24} \mathrm{H}_{28} \mathrm{~N}_{4} \cdot \frac{1}{2} \mathrm{H}_{2} \mathrm{O}(\mathrm{MM}=389.22 \mathrm{~g} / \mathrm{mol}): \mathrm{C}, 61.13 ; \mathrm{H}, 7.31 ; \mathrm{N}, 14.26 \%$. Selected IR (ATR-IR, $\left.\mathrm{cm}^{-1}\right)$ : $3394(\mathrm{~m}, \mathrm{~b})$ (H-O water of crystallization), $3043(\mathrm{w}), 3011$ (vw) (quinoliny C-H stretching), 2931 (w), 2864 (w), 2803 (m) (aliphatic C-H stretching), 1618 (s), 1601 (s), 1560 (m), 1503 (m), 1450 (m), 1423 (s) (C=C, C=N stretching of quinolyl rings), 837 (vs), 815 (vs), 785 (vs), 751 (vs) (C-H out of plane bending). ESI-MS in MeOH: $m / z=369.207$ $(100 \%)\left(\right.$ Calcd for $\left.[\mathrm{M}+\mathrm{H}]^{+}=369.208\right), m / z=391.190(100 \%)\left(\right.$ Calcd for $\left.[\mathrm{M}+\mathrm{Na}]^{+}=391.189\right)$ (Figure S5). ${ }^{1} \mathrm{H}$ NMR (DMSO- $d_{6}, 400 \mathrm{MHz}, \delta$ in ppm): $\delta=3.32\left(2 \mathrm{H}, \mathrm{s}, \mathrm{CH}_{2}\right.$-pipz), $3.76(2 \mathrm{H}$, s, $\mathrm{CH}_{2}$-py), $7.54(1 \mathrm{H}, \mathrm{t}), 7.62(1 \mathrm{H}, \mathrm{d}), 7.73(1 \mathrm{H}, \mathrm{t}), 7.94(2 \mathrm{H}, \mathrm{t}), 8.30(1 \mathrm{H}, \mathrm{d})$ (quinolyl protons). ${ }^{13}$ C NMR: (DMSO- $\left.d_{6}, 100 \mathrm{MHz}\right) \delta=52.96\left(\mathrm{CH}_{2}\right.$-pipz), $64.35\left(\mathrm{CH}_{2}\right.$-quinoline); 120.96, 126.07, $126.94,127.73,128.43,129.35,136.27,146.97,159.44$ (quinolyl carbons) (Figure S2).

\subsubsection{1,4-Bis[(3,4-dimethoxy-2-pyridinyl)methyl)]piperazine $\left(\mathrm{L}^{4} \cdot \frac{1}{4} \mathrm{H}_{2} \mathrm{O}\right)$}

To a mixture containing piperazine $(0.431 \mathrm{~g}, 5 \mathrm{mmol})$ and 3,4-dimethoxy-2-chlorometh yl-pyridine hydrochloride (2.24 g. $10 \mathrm{mmol})$ suspended in anhydrous $\mathrm{CH}_{3} \mathrm{CN}(40 \mathrm{~mL})$, triethylamine $(2.024 \mathrm{~g}, 20 \mathrm{mmol})$ was added and nitrogen gas was purged through the mixture, which was magnetically stirred under gentle reflux for 3 days, during which color turned brown. The resulting mixture was cooled in the refrigerator and filtered off to remove $\mathrm{Et}_{3} \mathrm{NHCl}$, and the solvent was removed under reduced pressure. The resulting residue was extracted with $\mathrm{CH}_{2} \mathrm{Cl}_{2}(15 \mathrm{~mL} \times 3)$ in $10 \% \mathrm{NaOH}(20 \mathrm{~mL})$ and saturated $\mathrm{NaCl}$ $(20 \mathrm{~mL})$, and then, it was washed with $\mathrm{H}_{2} \mathrm{O}(20 \mathrm{~mL} \times 3)$. The combined organic layers were collected and solvent was evaporated by rotary evaporator. The crude product was recrystallized from EtOAc with the aid of activated charcoal, followed by the addition of anhydrous $\mathrm{MgSO}_{4}$. The product was obtained as off-white solid after drying over $\mathrm{P}_{4} \mathrm{O}_{10}$ under vacuum (yield 1.0 g, 54\%). m.p. $=135-138^{\circ} \mathrm{C}$. Found: C, 61.13; H, 7.17; N, 14.19\%. Calcd for $\mathrm{C}_{24} \mathrm{H}_{28} \mathrm{~N}_{4} \mathrm{O}_{4} \cdot \frac{1}{2} \mathrm{H}_{2} \mathrm{O}(\mathrm{MM}=392.96 \mathrm{~g} / \mathrm{mol}): \mathrm{C}, 61.13 ; \mathrm{H}, 7.31 ; \mathrm{N}, 14.26 \%$. Selected IR (ATR-IR, cm ${ }^{-1}$ ): 3393 (w, b) (H-O water of crystallization), 3089 (vw) (pyridyl C-H stretching), 2965 (vw), 2932 (w), 2811 (m) (aliphatic C-H stretching), 1624 (w), 1580 (s), 1484 (s), 1444 (s), 1421 (s) (C=C, C=N stretching of pyridyl rings), 1296 (vs); 1256 (m), 1227 (m) (asymmetric C-O-C stretching), 1077 (vs), 994 (vs) (symmetric C-O-C stretching), 808 (s), 732 (s) (C-H out of plane bending). ESI-MS in MeOH: $m / z=389.219$ (100\%) (Calcd for $\left.[\mathrm{M}+\mathrm{H}]^{+}=389.218\right), m / z=411.200(100 \%)\left(\right.$ Calcd for $\left.[\mathrm{M}+\mathrm{Na}]^{+}=411.200\right) .{ }^{1} \mathrm{H} \mathrm{NMR}$ (DMSO- $d_{6}, 400 \mathrm{MHz}, \delta$ in ppm): $\delta=3.50\left(4 \mathrm{H}, \mathrm{s}, \mathrm{CH}_{2}-\mathrm{pipz}\right), 3.76(6 \mathrm{H}, \mathrm{s}), 3.86(6 \mathrm{H}, \mathrm{s})$ $\left(\mathrm{CH}_{3} \mathrm{O}\right.$-py), $7.02(2 \mathrm{H}, \mathrm{d}), 8.12(2 \mathrm{H}, \mathrm{d})$ (substituted pyridyl protons). ${ }^{13} \mathrm{C}$ NMR: (DMSO- $d_{6}$, $100 \mathrm{MHz}) \delta=52.98,55.74\left(\mathrm{CH}_{2}\right.$-pipz); 68.37, 60.61 ( $\mathrm{CH}_{2}$-py); 107.74, 143.96, 144.92, 151.65, 158.23 (pyridyl carbons) (Figure S3).

\subsubsection{1,4-Bis[(3,5-dimethyl-4-methoxy-2-pyridinyl)methyl)]piperazine $\left(\mathrm{L}^{5}\right)$}

To a mixture containing piperazine $(0.431 \mathrm{~g}, 5 \mathrm{mmol})$ and 3,5-dimethyl-4-methoxy-2chloromethylpyridine hydrochloride $(2.22 \mathrm{~g}, 10 \mathrm{mmol})$ suspended in anhydrous $\mathrm{CH}_{3} \mathrm{CN}$ $(40 \mathrm{~mL})$, anhydrous $\mathrm{K}_{2} \mathrm{CO}_{3}(2.07 \mathrm{~g}, 15 \mathrm{mmol})$ was added. Nitrogen gas was purged through the reaction mixture, which was magnetically stirred under gentle reflux for 3 days, during which color turned brown. The mixture was cooled in the refrigerator and filtered off, and then, the solvent was removed under reduced pressure. The resulting residue was extracted with $\mathrm{CH}_{2} \mathrm{Cl}_{2}(15 \mathrm{~mL} \times 3)$ in $10 \% \mathrm{NaOH}(20 \mathrm{~mL})$ and saturated $\mathrm{NaCl}(20 \mathrm{~mL})$, 
and then it washed with $\mathrm{H}_{2} \mathrm{O}(20 \mathrm{~mL} \times 3)$. The combined organic layers were collected and solvent was evaporated by rotary evaporator. The crude product was recrystallized from $\mathrm{Et}_{2} \mathrm{O}$ with the aid of activated charcoal, followed by the addition of anhydrous $\mathrm{MgSO}_{4}$. The product was obtained as off-white solid after drying over $\mathrm{P}_{4} \mathrm{O}_{10}$ under vacuum (yield 0.8 g, 42\%). m.p. $=140-143{ }^{\circ}$ C. Found: $\mathrm{C}, 68.85 ; \mathrm{H}, 8.52 ; \mathrm{N}, 14.22 \%$. Calcd for $\mathrm{C}_{22} \mathrm{H}_{32} \mathrm{~N}_{4} \mathrm{O}_{2}$ $(\mathrm{MM}=384.25 \mathrm{~g} / \mathrm{mol}): \mathrm{C}, 68.72 ; \mathrm{H}, 8.39 ; \mathrm{N}, 14.57 \%$. Selected IR (ATR-IR, $\left.\mathrm{cm}^{-1}\right): 2999$ (vw), (pyridyl C-H stretching), 2924 (w), 2810 (aliphatic C-H stretching), 1640 (w), 1560 (s), 1454 (s), 1397 (s), 1340 (m), 1289 (s) (C=C, C=N stretching of pyridyl rings), 1252 (s); 1147 (s) (asymmetric C-O-C stretching), 1094 (s), 1004 (vs) (symmetric C-O-C stretching), 769 (s) (C-H out of plane bending). ESI-MS in MeOH: $m / z=385.261(100 \%)\left(\right.$ Calcd for $\left.[\mathrm{M}+\mathrm{H}]^{+}=385.260\right)$, $m / z=407.242$ (Calcd for $\left.[\mathrm{M}+\mathrm{Na}]^{+}=407.242\right) .{ }^{1} \mathrm{H}$ NMR (DMSO- $d_{6}, 400 \mathrm{MHz}, \delta$ in ppm): $\left.\delta=2.17(3 \mathrm{H}, \mathrm{s}), 2.25(3 \mathrm{H}, \mathrm{s})\left(\mathrm{CH}_{3}-\mathrm{py}\right) ; 3.71(2 \mathrm{H}, \mathrm{s}), 3.49(2 \mathrm{H}, \mathrm{s}) \mathrm{CH}_{2}-\mathrm{pipz}\right) ; 3.32\left(3 \mathrm{H}, \mathrm{s}, \mathrm{CH}_{3} \mathrm{O}-\right) ; 8.09$ (1H, s, pyridyl proton). ${ }^{13} \mathrm{C}$ NMR: (DMSO- $\left.d_{6}, 100 \mathrm{MHz}\right) \delta=10.63,12.87\left(\mathrm{CH}_{3}-\right.$ py); $52.91\left(\mathrm{CH}_{2}-\right.$ pipz); 59.61, $62.68\left(\mathrm{CH}_{2}\right.$-py); 125.10, 126.11, 148.35, 156.76, 163.84 (pyridyl carbons) (Figure S4).

\subsubsection{Synthesis of $\mathrm{Cu}(\mathrm{II})$ Complexes}

The two complexes $\left[\mathrm{Cu}\left(\mathrm{L}^{1}\right) \mathrm{ClO}_{4}\right] \mathrm{ClO}_{4}\left(\mathbf{1}-\mathrm{ClO}_{4}\right)$ and $\left[\mathrm{Cu}\left(\mathrm{L}^{6}\right) \mathrm{ClO}_{4}\right] \mathrm{ClO}_{4}\left(\mathbf{6}-\mathrm{ClO}_{4}\right)$ were prepared and characterized according to the published procedure [6,47]. Characterization of 1-ClO : selected IR bands (ATR-IR, cm $^{-1}$ ): 2955 (vw), 2932 (vw), 2884 (vw) (aliphatic C-H stretching), 1612 (s), 1570 (w), 1488 (m), 1437 (s) (C=C, C=N stretching of pyridyl rings), 1082 (vs), 1052 (vs) ( $v_{\mathrm{as}}(\mathrm{Cl}-\mathrm{O})$ stretching of $\left.\mathrm{ClO}_{4}{ }^{-}\right)$. UV-VIS spectrum $\left(\lambda_{\max }, \mathrm{nm}\right.$ $\left.\left(\varepsilon, \mathrm{M}^{-1} \mathrm{~cm}^{-1}\right)\right)$ in $\mathrm{CH}_{3} \mathrm{CN}: 645$ (310). Molar conductivity, $\Lambda_{\mathrm{M}}\left(\mathrm{CH}_{3} \mathrm{CN}\right)=300$ and $\Lambda_{\mathrm{M}}$ $\left(\mathrm{H}_{2} \mathrm{O}\right)=188 \Omega^{-1} \mathrm{~cm}^{2} \mathrm{~mol}^{-1}$. Characterization of $6-\mathrm{ClO}_{4}$ : Selected IR bands $\left(\mathrm{KBr}, \mathrm{cm}^{-1}\right): 1112$ (vs), 1091 (vs) $\left(v_{\mathrm{a}}(\mathrm{Cl}-\mathrm{O})\right.$ stretching of $\left.\mathrm{ClO}_{4}^{-}\right)$. UV-VIS spectrum $\left(\lambda_{\max }, \mathrm{nm}\left(\varepsilon, \mathrm{M}^{-1} \mathrm{~cm}^{-1}\right)\right)$ in $\mathrm{CH}_{3} \mathrm{CN} 645$ (310) [6,47]. Molar conductivity, $\Lambda_{\mathrm{M}}\left(\mathrm{CH}_{3} \mathrm{CN}\right)=300 \Omega^{-1} \mathrm{~cm}^{2} \mathrm{~mol}^{-1}$

\subsection{6. $\left[\mathrm{Cu}\left(\mathrm{L}^{2}\right) \mathrm{ClO}_{4}\right] \mathrm{ClO}_{4}\left(2-\mathrm{ClO}_{4}\right)$}

A mixture of 1,4-bis[(6-(methyl)-(2-pyridinyl)methyl]piperazine $\left(\mathrm{L}^{2} \cdot \frac{1}{4} \mathrm{H}_{2} \mathrm{O}\right)(0.075 \mathrm{~g}$, $0.250 \mathrm{mmol})$ and $\mathrm{Cu}\left(\mathrm{ClO}_{4}\right)_{2} \cdot 6 \mathrm{H}_{2} \mathrm{O}(0.095 \mathrm{~g}, 0.256 \mathrm{mmol})$ were dissolved in $\mathrm{MeOH}(15 \mathrm{~mL})$. The intense blue solution was heated on steam bath for $5 \mathrm{~min}$, filtered through celite, and then allowed to crystallize at room temperature. The blue crystalline compound, which separated after 2 days, was collected by filtration, washed with propan-2-ol, $\mathrm{Et}_{2} \mathrm{O}$, and air dried (yield: $0.121 \mathrm{~g}$, 87\%). Found: $\mathrm{C}, 38.64 ; \mathrm{H}, 4.40 ; \mathrm{N}, 9.85 \%$. Calcd for $\mathrm{C}_{18} \mathrm{H}_{24} \mathrm{Cl}_{2} \mathrm{CuN}_{4} \mathrm{O}_{8}$ $(\mathrm{MM}=558.86 \mathrm{~g} / \mathrm{mol}): \mathrm{C}, 38.68 ; \mathrm{H}, 4.33 ; \mathrm{N}, 10.03 \%$. Selected IR bands (ATR-IR, $\left.\mathrm{cm}^{-1}\right): 3069$ (vw) (pyridyl C-H stretching), 2930 (w), 2869 (vw) (aliphatic C-H stretching), 1610 (m), 1578 (w), 1465 (m), 1443 (m) (C=C, C=N stretching of pyridyl rings), 1095 (vs), 1065 (vs) $\left(v_{\text {as }}(\mathrm{Cl}-\mathrm{O})\right.$ stretching of $\left.\mathrm{ClO}_{4}^{-}\right)$. UV-VIS spectrum $\left(\lambda_{\max }, \mathrm{nm}\left(\varepsilon, \mathrm{M}^{-1} \mathrm{~cm}^{-1}\right)\right)$ in $\mathrm{CH}_{3} \mathrm{CN}$ : $\sim 752$ (299). ESI-MS in $\mathrm{CH}_{3} \mathrm{CN}: m / z=458.035$ (Calcd for $\left[\mathrm{Cu}\left(\mathrm{L}^{2}\right) \mathrm{ClO}_{4}\right]^{+}=458.088$ ) (Figure S7); $m / z=98.949\left(\right.$ Calcd for $\left[\mathrm{ClO}_{4}\right]^{-}=98.95(100 \%) . \Lambda_{\mathrm{M}}\left(\mathrm{CH}_{3} \mathrm{CN}\right)=297 \Omega^{-1} \mathrm{~cm}^{2} \mathrm{~mol}^{-1}$.

\subsection{7. $\left[\mathrm{Cu}\left(\mathrm{L}^{3}\right) \mathrm{ClO}_{4}\right] \mathrm{ClO}_{4}\left(3-\mathrm{ClO}_{4}\right)$}

This complex was synthesized using a procedure similar to that described above except 1,4-bis[(2-quinolyl)methyl]piperazine $\left(\mathrm{L}^{3}\right)$ was used instead of $\mathrm{L}^{2}$. The product was further recrystallized from $\mathrm{MeOH}$ to afford green crystalline compound (yield: $87 \%$ ). Found: $\mathrm{C}, 45.60 ; \mathrm{H}, 3.84 ; \mathrm{N}, 8.81 \%$. Calcd for $\mathrm{C}_{24} \mathrm{H}_{24} \mathrm{Cl}_{2} \mathrm{CuN}_{4} \mathrm{O}_{8}(\mathrm{MM}=630.92 \mathrm{~g} / \mathrm{mol})$ : C, 45.69; H, 3.83; N, 8.88\%. Selected IR bands (ATR-IR, $\mathrm{cm}^{-1}$ ): 3071 (vw), 3032 (vw) (pyridyl C-H stretching), 2971 (vw), 2888 (vw) (aliphatic C-H stretching), 1617 (m), 1604 (m), $1567(\mathrm{w}), 1517(\mathrm{~m}), 1465(\mathrm{~m}), 1435(\mathrm{~m})$ (C=C, C=N stretching of quinolyl rings), 1076 (vs), 1063 (vs) $\left(v_{\mathrm{a}}(\mathrm{Cl}-\mathrm{O})\right.$ stretching of $\left.\mathrm{ClO}_{4}^{-}\right)$. UV-VIS spectrum $\left(\lambda_{\max }, \operatorname{nm}\left(\varepsilon, \mathrm{M}^{-1} \mathrm{~cm}^{-1}\right)\right)$ in $\mathrm{CH}_{3} \mathrm{CN}: \sim 565$ (sh), $\sim 618$ (sh), 745 (226). ESI-MS in $\mathrm{CH}_{3} \mathrm{CN}: m / z=530.033$ (Calcd for $\left.\left[\mathrm{Cu}\left(\mathrm{L}^{3}\right) \mathrm{ClO}_{4}\right]^{+}=530.088\right)\left(\right.$ Figure S8); $m / z=98.949\left(\right.$ Calcd for $\left[\mathrm{ClO}_{4}\right]^{-}=98.95(100 \%) . \Lambda_{\mathrm{M}}$ $\left(\mathrm{CH}_{3} \mathrm{CN}\right)=301 \Omega^{-1} \mathrm{~cm}^{2} \mathrm{~mol}^{-1}$. 


\subsection{8. $\left[\mathrm{Cu}\left(\mathrm{L}^{4}\right) \mathrm{Cl}\right] \mathrm{ClO}_{4} \cdot \frac{1}{2} \mathrm{H}_{2} \mathrm{O}(4-\mathrm{Cl})$}

To a well-stirred warm solution containing 1,4-bis[(3,4-dimethoxy-2-pyridinyl)methyl)]piperazine $\left(\mathrm{L}^{4}\right)(0.0971 \mathrm{~g} 0.25 \mathrm{mmol})$ and $\mathrm{CuCl}_{2} \cdot 2 \mathrm{H}_{2} \mathrm{O}(0.043 \mathrm{~g}, 0.25 \mathrm{mmol})$ dissolved in $\mathrm{MeOH}(15 \mathrm{~mL}), \mathrm{NaClO}_{4}(0.032 \mathrm{~g}, 0.26 \mathrm{mmol})$ was added, and the solution was allowed to stand at room temperature. After $1 \mathrm{~h}$, the well-shaped blue long needles were collected by filtration. These were washed with propan-2-ol and $\mathrm{Et}_{2} \mathrm{O}$ and then were air dried (yield: $81 \%$ ). Found: $\mathrm{C}, 40.31 ; \mathrm{H}, 4.91 ; \mathrm{N}, 9.40 \%$. Calcd for $\mathrm{C}_{20} \mathrm{H}_{28} \mathrm{Cl}_{2} \mathrm{CuN}_{4} \mathrm{O}_{12} \cdot \frac{1}{2} \mathrm{H}_{2} \mathrm{O}$ $(\mathrm{MM}=595.92 \mathrm{~g} / \mathrm{mol}): \mathrm{C}, 40.64 ; \mathrm{H}, 5.06 ; \mathrm{N}, 9.00 \%$. Selected IR bands (ATR-IR, $\left.\mathrm{cm}^{-1}\right): 3547$ $(\mathrm{m})\left(\mathrm{v}_{\mathrm{as}}(\mathrm{H}-\mathrm{O})\right.$ stretching of $\left.\mathrm{H}_{2} \mathrm{O}\right) ; 3090(\mathrm{vw})$ (pyridyl C-H stretching), $2947(\mathrm{w}), 2883(\mathrm{vw})$, 2837 (vw) (aliphatic C-H stretching); 1597 (s), 1497 (s), 1432 (m), 1436 (m) (C=C, C=N stretching of pyridyl rings), 1304 (s), 1232 (s) (asymmetric C-O-C stretching), 1084 (s), 1052 (vs) $\left(v_{\text {as }}\left(\mathrm{Cl}\right.\right.$-O) stretching of $\left.\mathrm{ClO}_{4}^{-}\right)$. UV-VIS spectrum $\left(\lambda_{\max }, \mathrm{nm}\left(\varepsilon, \mathrm{M}^{-1} \mathrm{~cm}^{-1}\right)\right)$ in $\mathrm{CH}_{3} \mathrm{CN}$ : 771 (324). ESI-MS (MeCN): $m / z=486.109$ (Calcd for $\left.\left[\mathrm{Cu}\left(\mathrm{L}^{4}\right) \mathrm{Cl}\right]^{+}=486.109\right), m / z=98.949$ $\left(\right.$ Calcd for $\left.\left[\mathrm{ClO}_{4}\right]^{-}=98.95\right)(100 \%) . \Lambda_{\mathrm{M}}\left(\mathrm{CH}_{3} \mathrm{CN}\right)=145 \Omega^{-1} \mathrm{~cm}^{2} \mathrm{~mol}^{-1}$.

\subsection{9. $\left[\mathrm{Cu}\left(\mathrm{L}^{5}\right) \mathrm{Cl}\right] \mathrm{PF}_{6}(5-\mathrm{Cl})$}

To mixture of 1,4-bis[(3,5-dimethyl-4-methoxy-2-pyridinyl)methyl)]-piperazine ( $\left.\mathrm{L}^{5}\right)$ $(0.105 \mathrm{~g} 0.25 \mathrm{mmol})$ and $\mathrm{CuCl}_{2} \cdot 2 \mathrm{H}_{2} \mathrm{O}(0.043 \mathrm{~g}, 0.25 \mathrm{mmol})$ dissolved in $\mathrm{MeOH}(15 \mathrm{~mL})$, $\left(\mathrm{NH}_{4}\right) \mathrm{PF}_{6}(0.041 \mathrm{~g}, 0.25 \mathrm{mmol})$ was added. The resulting blue solution was warmed for $5 \mathrm{~min}$ on a steam bath and then allowed to stand at room temperature. On the following day, the separated precipitate was collected by filtration. Recrystallization of the crude product from warm $\mathrm{MeOH}$ resulted in unidentified green precipitate, which was discarded, and evaporation of the blue solution let to the isolation of shiny blue well-shaped crystals suitable for X-ray. These were washed with propan-2-ol and $\mathrm{Et}_{2} \mathrm{O}$ and then were air dried (yield: 70\%). Found: $\mathrm{C}, 41.72 ; \mathrm{H}, 5.25 ; \mathrm{N}, 8.83 \%$. Calcd for $\mathrm{C}_{22} \mathrm{H}_{32} \mathrm{ClCuF}_{6} \mathrm{~N}_{4} \mathrm{O}_{2} \mathrm{P}$ $(\mathrm{MM}=628.48 \mathrm{~g} / \mathrm{mol}): \mathrm{C}, 42.04 ; \mathrm{H}, 5.13 ; \mathrm{N}, 8.91 \%$. Selected IR bands (ATR-IR, $\left.\mathrm{cm}^{-1}\right): 2926$ (vw), 2880 (vw) (aliphatic C-H stretching); 1599 (m), 1496 (w), 1477 (m), 1461 (m), 1403 (m) $(\mathrm{C}=\mathrm{C}, \mathrm{C}=\mathrm{N}$ stretching of pyridyl rings), $1287(\mathrm{~m}), 1245(\mathrm{~m})$ (asymmetric $\mathrm{C}-\mathrm{O}-\mathrm{C}$ stretching), 1084 (s), 832 (vs) $\left(v_{\text {as }}(\mathrm{F}-\mathrm{P})\right.$ stretching of $\left.\mathrm{PF}_{6}{ }^{-}\right)$. UV-VIS spectrum $\left(\lambda_{\max }, \mathrm{nm}\left(\varepsilon, \mathrm{M}^{-1} \mathrm{~cm}^{-1}\right)\right)$ in $\mathrm{CH}_{3} \mathrm{CN}$ : 765 (352). ESI-MS (MeCN): $m / z=482.150$ (Calcd for $\left[\mathrm{Cu}\left(\mathrm{L}^{5}\right) \mathrm{Cl}\right]^{+}=482.159$ ) (100\%) (Figure S9). $\Lambda_{\mathrm{M}}\left(\mathrm{CH}_{3} \mathrm{CN}\right)=162 \Omega^{-1} \mathrm{~cm}^{2} \mathrm{~mol}^{-1}$.

\subsubsection{0. $\left[\mathrm{Cu}\left(\mathrm{L}^{1}\right) \mathrm{Cl}\right] \mathrm{PF}_{6}(\mathbf{1}-\mathrm{Cl})$}

This complex was synthesized using a similar procedure as that described above for $\left[\mathrm{Cu}\left(\mathrm{L}^{5}\right) \mathrm{Cl}\right] \mathrm{PF}_{6}(5-\mathrm{Cl})$, except 1,4-bis[(2-pyridinyl)methyl]piperazine $\left(\mathrm{L}^{1}\right)$ was used instead of $\mathbf{L}^{5}$ (Yield: $68 \%$ ): Found: $\mathrm{C}, 37.55 ; \mathrm{H}, 3.93 ; \mathrm{N}, 10.84 \%$. Calcd for $\mathrm{C}_{16} \mathrm{H}_{20} \mathrm{ClCuF}_{6} \mathrm{~N}_{4} \mathrm{P}(\mathrm{MM}$ $=512.32 \mathrm{~g} / \mathrm{mol}): \mathrm{C}, 37.51 ; \mathrm{H}, 3.93 ; \mathrm{N}, 10.94 \%$. Selected IR bands $\left(\right.$ ATR-IR, $\left.\mathrm{cm}^{-1}\right): 2927(\mathrm{vw})$, 2890 (vw) (aliphatic C-H stretching), 1607 (s), 1485 (m), 1444 (s), (C=C, C=N stretching of pyridyl rings), 1269 (s) (asymmetric C-O-C stretching), 1085 (s) (symmetric C-O-C stretching), 829 (vs) $\left(v_{\text {as }}(\mathrm{P}-\mathrm{F})\right.$ stretching of $\left.\mathrm{PF}_{6}{ }^{-}\right)$. UV-VIS spectrum $\left(\lambda_{\max }, \mathrm{nm}\left(\varepsilon, \mathrm{M}^{-1} \mathrm{~cm}^{-1}\right)\right)$ in $\mathrm{CH}_{3} \mathrm{CN}$ : 770 (304). ESI-MS $\left(\mathrm{CH}_{3} \mathrm{CN}\right): \mathrm{m} / z=366.066\left(\mathrm{Calcd}\right.$ for $\left.\left[\mathrm{Cu}\left(\mathrm{L}^{1}\right) \mathrm{Cl}\right]^{+}=366.077\right)$ (Figure S6). $\Lambda_{\mathrm{M}}\left(\mathrm{CH}_{3} \mathrm{CN}\right)=160 \Omega^{-1} \mathrm{~cm}^{2} \mathrm{~mol}^{-1}$.

\subsection{DNA Cleavage}

The cleavage activity of the complexes towards pBR322 plasmid DNA (Carl Roth) was studied using gel electrophoresis. In a typical experiment, $1 \%$ agarose (Lonza) gels in $0.5 \times$ TBE buffer (Fisher Scientific, $50 \mathrm{mM}$ Tris, $45 \mathrm{mM}$ boric acid, $0.5 \mathrm{mM}$ EDTA) containing ethidium bromide $(0.2 \mu \mathrm{g} / \mathrm{mL}$, Fisher Scientific) were used to monitor the conversion of supercoiled (form I) pBR322 into its nicked form (form II) and linear form (form III). If not stated otherwise, the experiments were carried out at least three times in order to assure reproducibility of the data and generate a reliable standard deviation. All experiments were carried out under normal air atmosphere without exclusion of light.

Plasmid DNA $(0.025 \mu \mathrm{g} / \mu \mathrm{L}$, Carl Roth) in a buffer solution, $10 \mathrm{mM}$ MOPS (Fisher Scientific) $\mathrm{pH} 7.4$, was treated with different concentrations of the complexes or ligands 
$(60,120,180,300,420$, and $540 \mu \mathrm{M}$, stock solutions of the complexes in acetonitrile were diluted to the final concentrations in $0.25-12 \%$ acetonitrile/deionized water). Deionized water (Millipore system) was added up to a final volume of $8 \mu \mathrm{L}$ before the samples were incubated for given time at $37^{\circ} \mathrm{C}$ and $300 \mathrm{rpm}$ in a thermomixer (Eppendorf).

For analysis, $1.5 \mu \mathrm{L}$ of loading buffer ( $3.7 \mathrm{mM}$ bromophenol blue and $1.2 \mathrm{M}$ saccharose in deionized water), was added and the sample was loaded onto the gel. Electrophoresis was carried out at $40 \mathrm{~V}$ for $2 \mathrm{~h}$ at room temperature using an electrophoresis unit (Carl Roth) in $0.5 \times$ TBE buffer. Bands were visualized using fluorescence emission of ethidium bromide and photographed using a gel documentation system (Bio-Rad, Gel Doc ${ }^{\mathrm{TM}}$ EZ imager). DNA bands were quantified using Bio-Rad Laboratories Image Lab Software 5.2.1. In all assays, the intensity of the bands was measured using a reference DNA sample (no complex added) as standard. Taking into account that the supercoiled form I of plasmid DNA has a smaller affinity to bind ethidium bromide, its intensity was multiplied with a correction factor of 1.22 [59]. The average of results for each concentration was related to the DNA reference in percent. The statistical analysis was carried out with Microsoft Excel 2010. The DNA marker consisted of 50\% purified, linearized (by EcoRI nuclease) and 50\% nonlinearized plasmid pBR322 DNA.

\subsubsection{Kinetics of DNA Cleavage}

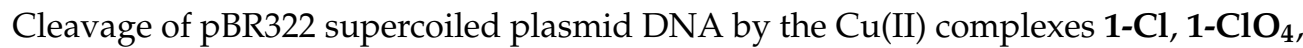
2- $\mathrm{ClO}_{4}$, and $3-\mathrm{ClO}_{4}$ was studied at $37{ }^{\circ} \mathrm{C}$ in MOPS buffer $(10 \mathrm{mM})$ with a $\mathrm{pH}$ value of 7.4 , over varying incubation times $(10,20,40,60,90$, and $120 \mathrm{~min})$ and using different concentrations of the complexes ( $0 \mu \mathrm{M}$ as a reference, $60,120,180,300,420$, and $540 \mu \mathrm{M})$. In accordance with previously published procedures $[3,4,6]$, the percentages of form II were quantified using Bio-Rad Laboratories Image Lab Software 5.2.1 and were plotted against time for each complex concentration and fitted in Origin. To take into consideration the varying starting amount of form II when comparing experiments with different incubation times, the results were normalized (percentage of form II at $0 \mathrm{~min}=0 \%$ ) through subtraction of the reference DNA sample (no complex added). The observed rate constants $\left(k_{\mathrm{obs}}\right)$ were determined based on equation (1) (pseudo first-order kinetics) using Microsoft Excel 2010.

$$
y=\left(100-y_{0}\right)\left(1-\exp \left(-k_{o b s} t\right)\right)
$$

Herein, $y$ represents the percentage of a specific form of DNA at a time $t, y_{0}$ is the percentage of that form at $t=0$ (for form II $y_{0}=0$ ), and $k_{\mathrm{obs}}$ is the hydrolysis rate. The calculated values of $1 / k_{\text {obs }}$ were then plotted against the complex concentrations $1 /$ [complex] and fitted to equation (3) (pseudo first-order Michaelis-Menten analysis, linear fit rearranged from equation (2)) to determine the catalytic rate constant $k_{\text {cat }}$, which is interpreted as the maximum rate of cleavage at complex saturation $\left(k_{\text {cat }}=v_{\max }\right)$, and the affinity constant $K_{M}$ :

$$
\begin{gathered}
k_{\text {obs }}=k_{\text {cat }} \cdot[\text { complex }] /\left(K_{M}+[\text { complex }]\right) \\
1 / k_{\text {obs }}=\left(K_{M} / k_{\text {cat }}\right) \cdot(1 /[\text { complex }])+1 / k_{\text {cat }}
\end{gathered}
$$

The analysis of data was carried out with Microsoft Excel 2010.

\subsubsection{ROS Scavenger Study}

Cleavage of pBR322 plasmid DNA $(0.025 \mu \mathrm{g} / \mu \mathrm{L})$ in MOPS buffer $(10 \mathrm{mM}, \mathrm{pH} 7.0)$ by complexes 1-ClO $\mathbf{C l}_{4}-\mathbf{3}-\mathrm{ClO}_{4}(540 \mu \mathrm{M})$ in the presence of ROS scavengers for $2 \mathrm{~h}$ at $37^{\circ} \mathrm{C}$ was studied. Experiments with ROS scavengers were carried out as described above using $400 \mathrm{mM}$ DMSO, $0.5 \mathrm{mM}$ potassium iodide, or $0.5 \mathrm{mM}$ sodium azide. Illustrated is the average of three experiments, the standard deviation is shown as error bars. As a control experiment, DNA was incubated with each ROS scavenger in absence of the complex, and 
one sample without the addition of any ROS showing the original activity. Analysis of data was done with Microsoft Excel 2010.

\subsubsection{Cleavage of BNPP}

For the cleavage of BNPP $(270 \mu \mathrm{M}$, Sigma-Aldrich), the $\mathrm{Cu}(\mathrm{II})$ complexes were used at a concentration of $540 \mu \mathrm{M}$ in $10 \mathrm{mM}$ MOPS (pH 7.4) in the same cuvette with a volume of 1 $\mathrm{mL}$. Before each measurement, the background was recorded with $540 \mu \mathrm{M}$ complex, $10 \mathrm{mM}$ MOPS buffer ( $\mathrm{pH}$ 7.4) in Millipore water. As a positive control, a sample containing 0.05 units $\mathrm{mL}^{-1}$ phosphodiesterase I from Crotalus adamanteus venom (Sigma-Aldrich) was used. As a negative control, a sample just containing BNPP in buffer was used. The samples were incubated for 2,48 , and $96 \mathrm{~h}$ at $37^{\circ} \mathrm{C}$ and $300 \mathrm{rpm}$ in a thermomixer (Eppendorf). UV/VIS spectra were recorded with a UV/VIS spectrometer Cary 100 (Agilent Technologies) at $25^{\circ} \mathrm{C}$ in a region of $190-900 \mathrm{~nm}$. The analysis of the data was carried out with Microsoft Excel 2010, the graphical representation with Julia 0.6.3.

\subsubsection{Cell Culture and Cell Viability Assay}

A2780 cells (human ovarian carcinoma cells from ECACC) were purchased from Merck. Human dermal fibroblasts isolated from neonate foreskin biopsies [60] after ethical approval (EA1/081/13, Ethics Committee from the Charité Campus Mitte, Berlin) and with informed parental consent, were kindly provided by the Institute of Pharmacy (Freie Universität Berlin). Cells were routinely maintained in DMEM with GlutaMAX (Dulbecco's minimal essential medium, Thermo Fisher Scientific), 15\% FCS (Biochrom AG), and 1\% penicillin/streptomycin (Thermo Fisher Scientific) at $37^{\circ} \mathrm{C}$ and $5 \% \mathrm{CO}_{2}$.

For MTT assay, $1 \times 10^{5}$ cells $/ \mathrm{mL}$ were seeded into microtest plates 96 well, F (Sarstedt) and incubated overnight at $37{ }^{\circ} \mathrm{C}$ and $5 \% \mathrm{CO}_{2}$. The next day, medium was replaced with $100 \mu \mathrm{L}$ per well fresh medium containing dilutions of the test compounds (in duplicates). After $48 \mathrm{~h}$ of incubation, $100 \mu \mathrm{L}$ fresh medium, $10 \mu \mathrm{L}$ MTT (3-(4,5-dimethylthiazol-2yl)-2,5-diphenyltetrazolium bromide), and $5 \mathrm{mg} / \mathrm{mL}$ stock solution in PBS (Sigma) were added in each well. Incubation was then pursued for $4 \mathrm{~h}$ at $37{ }^{\circ} \mathrm{C}$ and $5 \% \mathrm{CO}_{2}$. The supernatant was then discarded and formazan crystals were solubilized in $100 \mu \mathrm{L} /$ well isopropanol with $0.04 \mathrm{M} \mathrm{HCl}$ (15 min on a plate shaker). Absorbance was read in a microplate reader (Tecan Infinite M200 PRO) at $550 \mathrm{~nm}$. Assays were repeated at least three times independently. Relative cell viabilities were calculated by dividing the average absorbance values of duplicates by the absorbance value of untreated cells. The averages of at least three experiments were then plotted with their SEM against concentration. $\mathrm{IC}_{50}$ values were calculated from nonlinear dose-response curves (log inhibitor vs. normalized response-variable slope) fitted with Microsoft Excel 2010.

\section{Conclusions}

Two series of five-coordinate perchlorato and chlorido $\mathrm{Cu}(\mathrm{II})$-based piperazine complexes: $\left[\mathrm{Cu}(\mathrm{L}) \mathrm{ClO}_{4}\right] \mathrm{ClO}_{4} \mathrm{~L}=\mathrm{L}^{1}\left(\mathbf{1}-\mathrm{ClO}_{4}\right), \mathrm{L}^{2}\left(\mathbf{2}-\mathrm{ClO}_{4}\right), \mathrm{L}^{3}\left(\mathbf{3}-\mathrm{ClO}_{4}\right)$ and $\mathrm{L}^{6}\left(\mathbf{6}-\mathrm{ClO}_{4}\right)$, and $\left[\mathrm{Cu}\left(\mathrm{L}^{1}\right) \mathrm{Cl}\right] \mathrm{PF}_{6}(\mathbf{1 - C l}),\left[\mathrm{Cu}\left(\mathrm{L}^{4}\right) \mathrm{Cl}\right] \mathrm{ClO}_{4} \cdot \frac{1}{2} \mathrm{H}_{2} \mathrm{O}(4-\mathrm{Cl})$, and $\left[\mathrm{Cu}\left(\mathrm{L}^{5}\right) \mathrm{Cl}\right] \mathrm{PF}_{6}(5-\mathrm{Cl})$ where $\mathrm{L}^{1}-\mathrm{L}^{6}$ refer to 1,4-bis[(2-pyridinyl)methyl]piperazine, 1,4-bis[(6-methyl)-2-pyridinyl)methyl]piper azine, 1,4-bis[(2-quinolyl)methyl]piperazine, 1,4-bis[(3,4-dimethoxy-2-pyridinyl)methyl)]pi perazine, 1,4-bis[(3,5-dimethyl-4-methoxy-2-pyridinyl)methyl)]piperazine, and 1,4-bis[(2pyridinyl)-(2-ethyl)]piperazine were synthesized and characterized. In these complexes the coordinated chloride or perchlorate ligands are weakly bound to the $\mathrm{Cu}(\mathrm{II})$ center, and as a result, they are hydrolyzed in aqueous acetonitrile solutions to the corresponding aqua species $\left[\mathrm{Cu}(\mathrm{L})\left(\mathrm{H}_{2} \mathrm{O}\right)\right]^{2+}$. Similar species were also formed in five-coordinate complexes, $\left[\mathrm{M}\left(\mathrm{L}^{\prime}\right) \mathrm{X}\right] \mathrm{ClO}_{4} / \mathrm{PF}_{6}\left(\mathrm{M}=\mathrm{Cu}(\mathrm{II})\right.$ or $\mathrm{Co}(\mathrm{II}), \mathrm{L}^{\prime}$ = tripod-pyridyl tetraamine ligands) under comparable conditions $[3,4,6,61]$.

The nucleolytic activity of the synthesized $\mathrm{Cu}(\mathrm{II})$ complexes towards plasmid DNA cleavage at near-physiological conditions $\left(\mathrm{pH}=7.4,37^{\circ} \mathrm{C}\right)$ was studied and their cytotoxicity was investigated. Under this condition, the catalytic rate constant, $k_{\text {cat }}$, for DNA cleavage 
activity by the complexes decreases in the order: $1-\mathrm{Cl} \approx 1-\mathrm{ClO}_{4}>3-\mathrm{ClO}_{4} \geq 2-\mathrm{ClO}_{4}$, with rate enhancement up to 23 million over the uncatalyzed DNA for complex $\mathbf{1 - C l} / \mathbf{1 - C l O}$. Complexes 4-Cl, 5- $\mathbf{C l}$, and $\mathbf{6}-\mathrm{ClO}_{4}$ as well as all ligands were inactive. The mechanistic pathway for DNA cleavage by these complexes revealed that while complex 1 prefers the oxidative mechanism, complexes $\mathbf{2}-\mathrm{ClO}_{4}$ and $\mathbf{3}-\mathrm{ClO}_{4}$ proceed predominantly via a hydrolytic mechanism. Obviously, this depends on the ligand skeleton and steric hindrance encountered by the ligands, as demonstrated by the X-ray structures of complex 5-Cl in this work and in the previously structurally characterized $\mathbf{6}-\mathbf{C l O}_{4}$ [47]. It is not clear at the moment why the mechanism is different in the two indicated pairs of compounds. Interestingly, under comparable conditions, very high DNA catalytic cleavage enhancements by a factor of 100-1100 million have been reported for some mononuclear $\mathrm{Cu}(\mathrm{II})$ complexes [17,62-64].

Under pseudo-Michaelis-Menten first-order kinetics at $\mathrm{pH} 7.0$ and $37{ }^{\circ} \mathrm{C}$, the catalytic rate constants $k_{\text {cat }}$ for the DNA cleavage by a series of five-coordinate chlorido$\mathrm{Co}(\mathrm{II})$-tripod amine complexes were reported to decrease in the order: $[\mathrm{Co}(\mathrm{BPQA}) \mathrm{Cl}]^{+}>$ $[\mathrm{Co}(6-\mathrm{MeTPA}) \mathrm{Cl}]^{+}>[\mathrm{Co}(\mathrm{BQPA}) \mathrm{Cl}]^{+} \geq[\mathrm{Co}(\mathrm{TPA}) \mathrm{Cl}]^{+} \geq\left[\mathrm{Co}\left(6-\mathrm{Me}_{2} \mathrm{TPA}\right) \mathrm{Cl}\right]^{+}(\mathrm{TPA}=\operatorname{tris}(2-$ pyridylmethyl)amine, 6-MeTPA $=$ [((6-methyl-2-pyridyl)methyl)bis(2-pyridylmethyl) $]$ amine, 6- $\mathrm{Me}_{2} \mathrm{TPA}=[($ bis(6-methyl-2-pyridyl)methyl)-(2-pyridylmethyl) $]$ amine, BPQA = [bis(2pyridylmethyl)-(2quinolylmethyl)]amine, and BQPA = [bis(2-quinolylmethyl)-(2-pyridylme thyl)]amine) [4]. The mechanistic pathway in this series was mainly hydrolytic, where the steric skeletal environment around the central $\mathrm{Co}$ (II) enhances the release of the coordinated chloride ligand but also indicates that large increase in the steric environment at the 6th position of the pyridyl groups suppresses the approach of DNA to the metal center [4]. A parallel trend was also observed in another series of compounds, where methyl and methoxy groups were incorporated at the 3-5 positions of the pyridyl groups with no substituents at the 6th position [3]. Under comparable conditions, the linear tetradentate-based piperazine $\mathrm{Cu}(\mathrm{II})$ complexes under investigations revealed the reactivity order: $\mathbf{1 - C l} / \mathrm{ClO}_{4}$ $>3-\mathrm{ClO}_{4} \geq 2-\mathrm{ClO}_{4}$ with lack of reactivity for $4-\mathrm{Cl}, 5-\mathrm{Cl}$ and $6-\mathrm{ClO}_{4}$. The interpretation of the reactivity order in the former three complexes cannot be attributed to the steric effect only but the change in the mechanistic DNA cleavage also must be taken into account that complexes $\mathbf{2}$ and $\mathbf{3}$ proceed via hydrolytic mechanism, which is different from that determined in $\mathbf{1}$ as predominantly through oxidative mechanism.

The cytotoxic properties of the title $\mathrm{Cu}$ (II) complexes and their corresponding ligands were investigated in vitro in human ovarian carcinoma cells A2780 and human fibroblasts. Only the complexes $\mathbf{1 - C l O} \mathbf{C l}_{4}, 3-\mathrm{ClO}_{4}$, and 5- $\mathrm{Cl}$ were found to be cytotoxic against cancer cells ( $\mathrm{IC}_{50}$ 30-40 $\mu \mathrm{M}$ ), whereas the other complexes did not show cytotoxic activity. The cytotoxicity value of $3-\mathrm{ClO}_{4}$ in fibroblasts was the highest (lowest $\mathrm{IC}_{50}$ ) among the studied complexes, and the complex exhibited no toxicity towards human fibroblasts, a property which suggests its selectivity for cancer cells over healthy cells. The elevated lipophilicity of the quinolyl-containing compound is most likely responsible for the observed increase of cytotoxicity for $3-\mathrm{ClO}_{4}$. A similar trend was also observed in $[\mathrm{Cu}(\mathrm{BQPA}) \mathrm{Cl}] \mathrm{ClO}_{4} / \mathrm{PF}_{6}$, where BQPA = [bis(2-quinolylmethyl)-(2-pyridylmethyl)]amine [61]. There is no correlation between DNA cleavage activity and cytotoxicity. For example, 5-Cl, which did not show any DNA cleavage activity, was cytotoxic, whereas $\mathbf{1 - C l}$ and $\mathbf{1 - C 1 O}$, which revealed DNA cleavage of comparable activity surprisingly showed different cytotoxic behavior. The latter one is toxic in cancer cells and fibroblasts but the first one is not active in either cell line. Variations of the counter ions of the complexes or differences in their DNA cleavage mechanisms (oxidative/hydrolytic) do not clearly correlate with the differences in the cytotoxic activities indicating that interactions with other biological targets within the cells might be responsible for the cytotoxic effects. 
Supplementary Materials: The following are available online at https:/ /www.mdpi.com/2304-674 $0 / 9 / 2 / 12 / s 1$, the CIF and the checkCIF output files are included in the Supplementary Materials. These data can be obtained free of charge from The Cambridge Crystallographic Data Centre via www. ccdc.cam.ac.uk/data_request/cif. Supplementary associated with crystal structure determinations and Figure S1, Figure S2, Figure S3, and Figure S4 show the ${ }^{1} \mathrm{H}$ and ${ }^{13} \mathrm{C}$ NMR spectra of ligands $\mathrm{L}^{1}-\mathrm{L}^{4}$; Figure S5: ESI-MS of $\mathrm{L}^{2}$ and $\mathrm{L}^{3}$; Figure S6, Figure S7, Figure S8, and Figure S9: ESI mass spectra of 1-Cl, 2-ClO, $3-\mathrm{ClO}_{4}$, and 5-Cl, respectively; Figure S10: Cleavage of pBR322 plasmid DNA by complexes; Figure S11: Cleavage of pBR322 plasmid DNA by complexes and ligands; Figure S12: UV-VIS spectra of BNPP $(50 \mu \mathrm{M})$ at $\mathrm{pH}=7.4$ in the absence and presence of phosphodiesterase; Figure S13 and Figure S14: UV-VIS spectra of BNPP $(270 \mu \mathrm{M})$ at pH 7.4 in the presence of $\mathrm{Cu}(\mathrm{II})$ complexes after 2 and 96 h, incubation; Figure S15: Fluorescence spectra of TPA and PBSF after incubation with/without $\left[\mathrm{Cu}\left(\mathrm{L}^{1}\right) \mathrm{ClO}_{4}\right] \mathrm{ClO}_{4}\left(\mathbf{1}-\mathrm{ClO}_{4}\right)$; and Figure S16: Results of the MTT assay in A2780 cells and human fibroblasts of $\mathrm{Cu}(\mathrm{II})$ complexes and their ligands of this article can be found in the online version.

Author Contributions: Conceptualization, N.K. and S.S.M.; methodology, N.K., F.A.M., R.C.F. and S.S.M.; validation, N.K., S.S.M., and F.A.M.; formal analysis, S.D.K., Y.N., V.H., and R.C.F.; investigation, S.D.K., Y.N., V.H., F.R.L., J.R.L., E.M., and R.C.F.; data curation, S.D.K., Y.N., and V.H.; writing-original draft preparation, F.A.M., N.K., and S.S.M.; writing-review and editing, N.K., F.A.M., and S.S.M.; visualization, S.D.K. and Y.N.; supervision, N.K., F.A.M., and S.S.M.; project administration, N.K., F.A.M., and S.S.M. All authors have read and agreed to the published version of the manuscript.

Funding: This research was funded by Deutsche Forschungsmeinschaft (DFG) grant number GRK 1582 (S.D.K. and N.K.).

Institutional Review Board Statement: The study was conducted according to the guidelines of the Declaration of Helsinki, and approved by the Ethics Committee of Charité Campus Mitte Berlin (EA1/081/13).

Informed Consent Statement: Informed consent was obtained from all subjects involved in the study.

Data Availability Statement: Not applicable.

Acknowledgments: S.S.M. acknowledges financial support by the Department of Chemistry-University of Louisiana at Lafayette. Y.N. and N.K. thank the Institute of Pharmacy (FU Berlin) for providing fibroblast cells and Stefanie Wedepohl for assistance in cell culture. F.A.M. thanks NAWI Graz for support.

Conflicts of Interest: The authors declare no conflict of interest.

\section{References}

1. Schroeder, G.K.; Lad, C.; Wyman, P.; Williams, N.H.; Wolfenden, R. The time required for water attack at the phosphorus atom of simple phosphodiesters and of DNA. Proc. Natl. Acad. Sci. USA 2006, 103, 4052-4255. [CrossRef]

2. Cowan, J.A. Role of Metal Ions in Promoting DNA Binding and Cleavage by Restriction Endonucleases. In Restriction Endonucleases; Pingoud, A.M., Ed.; Springer: Berlin/Heidelberg, Germany, 2004; Volume 14, pp. 339-360.

3. Doniz Kettenmann, S.; Louka, F.R.; Marine, E.; Fischer, R.C.; Mautner, F.A.; Kulak, N.; Massoud, S.S. Efficient Artificial Nucleases for Mediating DNA Cleavage Based on Tuning the Steric Effect in the Pyridyl Derivatives of Tripod Tetraamine-Cobalt(II) Complexes. Eur. J. Inorg. Chem. 2018, 2018, 2322-2338. [CrossRef]

4. Massoud, S.S.; Perkins, R.S.; Louka, F.R.; Xu, W.; le Roux, A.; Dutercq, Q.; Fischer, R.C.; Mautner, F.A.; Handa, M.; Hiraoka, Y.; et al. Efficient hydrolytic cleavage of plasmid DNA by chloro-cobalt(II) complexes based on sterically hindered pyridyl tripod tetraamine ligands: Synthesis, crystal structure and DNA cleavage. Dalton Trans. 2014, 43, 10086-10103. [CrossRef] [PubMed]

5. Massoud, S.S.; Ledet, C.C.; Junk, T.; Bosch, S.; Comba, P.; Herchel, R.; Hošek, J.; Trávníček, Z.; Fischer, R.C.; Mautner, F.A. Dinuclear metal(II)-acetato complexes based on bicompartmental 4-chlorophenolate: Syntheses, structures, magnetic properties, DNA interactions and phosphodiester hydrolysis. Dalton Trans. 2016, 45, 12933-12950. [CrossRef] [PubMed]

6. Massoud, S.S.; Perkins, R.S.; Knierim, K.D.; Comiskey, S.P.; Otero, K.H.; Michel, C.L.; Juneau, W.M.; Albering, J.H.; Mautner, F.A.; $\mathrm{Xu}, \mathrm{W}$. Effect of the chelate ring size on the cleavage activity of DNA by copper(II) complexes containing pyridyl groups. Inorg. Chim. Acta 2013, 339, 177-184. [CrossRef]

7. Massoud, S.S.; Louka, F.R.; Xu, W.; Perkins, R.; Vicente, R.; Albering, J.H.; Mautner, F.A. DNA Cleavage by Structurally Characterized Dinuclear Copper(II) Complexes Based on Triazine. Eur. J. Inorg. Chem. 2011, 2011, 3469-3479. [CrossRef]

8. Sureshbabu, P.; Sudarga Tjakraatmadja, A.A.J.; Hanmandlu, C.; Elavarasan, K.; Kulak, N.; Sabiah, S. Mononuclear Cu(II) and $\mathrm{Zn}(\mathrm{II})$ complexes with a simple diamine ligand: Synthesis, structure, phosphodiester binding and DNA cleavage studies. RSC Adv. 2015, 5, 22405-22418. [CrossRef] 
9. Hormann, J.; van der Meer, M.; Sarkar, B.; Kulak, N. From Cyclen to 12-Crown-4 Copper(II) Complexes: Exchange of Donor Atoms Improves DNA Cleavage Activity. Eur. J. Inorg. Chem. 2015, 2015, 4722-4730. [CrossRef]

10. Wende, C.; Lüdtke, C.; Kulak, N. Copper Complexes of N-Donor Ligands as Artificial Nucleases. Eur. J. Inorg. Chem. 2014, 2014, 2597-2612. [CrossRef]

11. Sudarga Tjakraatmadja, A.A.J.; Lüdtke, C.; Kulak, N. Tuning the DNA binding and cleavage of bpa Cu(II) complexes by ether tethers with hydroxyl and methoxy groups. Inorg. Chim. Acta 2016, 452, 159-169. [CrossRef]

12. Soler, M.; Figueras, E.; Serrano-Plana, J.; González-Bártulos, M.; Massaguer, A.; Company, A.; Martínez, M.A.; Malina, J.; Brabec, V.; Feliu, L.; et al. Design, Preparation, and Characterization of Zn and Cu Metallopeptides Based On Tetradentate Aminopyridine Ligands Showing Enhanced DNA Cleavage Activity. Inorg. Chem. 2015, 54, 10542-10558. [CrossRef] [PubMed]

13. Mandegani, Z.; Asadi, Z.; Asadi, M.; Karbalaei-Heidari, H.R.; Rastegari, B. Synthesis, characterization, DNA binding, cleavage activity, cytotoxicity and molecular docking of new nano water-soluble $\left[\mathrm{M}\left(5-\mathrm{CH}_{2} \mathrm{PPh}_{3}-3,4-\mathrm{salpyr}\right)\right](\mathrm{ClO} 4)_{2}(\mathrm{M}=\mathrm{Ni}, \mathrm{Zn})$ complexes. Dalton Trans. 2016, 45, 6592-6611. [CrossRef] [PubMed]

14. Leite, S.M.G.; Lima, L.M.P.; Gama, S.; Mendes, F.; Orio, M.; Bento, I.; Paulo, A.; Delgado, R.; Iranzo, O. Copper(II) Complexes of Phenanthroline and Histidine Containing Ligands: Synthesis, Characterization and Evaluation of their DNA Cleavage and Cytotoxic Activity. Inorg. Chem. 2016, 55, 11801-11814. [CrossRef] [PubMed]

15. Qian, J.; Wang, L.; Gu, W.; Liu, X.; Tian, J.; Yan, S.-P. Efficient double-strand cleavage of DNA mediated by Zn(II)-based artificial nucleases. Dalton Trans. 2011, 40, 5617-5624. [CrossRef] [PubMed]

16. Li, D.D.; Tian, J.-L.; Gu, W.; Liu, X.; Yan, S.-P. A novel 1,2,4-triazole-based copper(II) complex: Synthesis, characterization, magnetic property and nuclease activity. J. Inorg. Biochem. 2010, 104, 171-179. [CrossRef]

17. Wang, J.T.; Xia, Q.; Zheng, X.-H.; Chen, H.-Y.; Chao, H.; Mao, Z.-W.; Ji, L.N. An effective approach to artificial nucleases using copper(II) complexes bearing nucleobases. Dalton Trans. 2010, 39, 2128-2136. [CrossRef]

18. Sreedhara, A.; Freed, J.D.; Cowan, J.A. Efficient Inorganic Deoxyribonucleases. Greater than 50-Million-Fold Rate Enhancement in Enzyme-Like DNA Cleavage. J. Am. Chem. Soc. 2000, 122, 8814-8824. [CrossRef]

19. Parveen, S.; Cowan, J.A.; Zhen Yu, Z.; Arjmand, F. Enantiomeric copper based anticancer agents promoting sequence-selective cleavage of G-quadruplex telomeric DNA and non-random cleavage of plasmid DNA. Metallomics 2020, 12, 988-999. [CrossRef]

20. Majumder, S.; Pasayat, S.; Panda, A.K.; Dash, S.P.; Roy, S.; Biswas, A.; Varma, M.E.; Joshi, B.N.; Garribba, E.; Kausar, C.; et al Monomeric and Dimeric Oxidomolybdenum(V and VI) Complexes, Cytotoxicity, and DNA Interaction Studies: Molybdenum Assisted C=N Bond Cleavage of Salophen Ligands. Inorg. Chem. 2017, 56, 11190-11210. [CrossRef]

21. Yu, Z.; Cowan, J.A. Metal Complexes Promoting Catalytic Cleavage of Nucleic Acids-Biochemical Tools and Therapeutics. Curr Opin Chem. Biol. 2018, 43, 37-42. [CrossRef]

22. Peng, B.; Gao, Z.; Li, X.; Li, T.; Chen, G.; Zhou, M.; Zhang, J. DNA binding, DNA cleavage and HSA interaction of several metal complexes containing $N$-(2-hydroxyethyl)- $N^{\prime}$-benzoylthiourea and 1,10-phenanthroline ligands. J. Biol. Inorg. Chem. 2016, 21, 903-916. [CrossRef] [PubMed]

23. Joyner, J.C.; Reichfield, J.; Cowan, J.A. Factors Influencing the DNA Nuclease Activity of Iron, Cobalt, Nickel, and Copper Chelates. J. Am. Chem. Soc. 2011, 133, 15613-15626. [CrossRef] [PubMed]

24. Li, D.-D.; Huang, F.-P.; Chen, G.-J.; Gao, C.-Y.; Tian, J.-L.; Gu, W.; Liu, X.; Yan, S.-P. Four new copper(II) complexes with 1,3-tpbd ligand: Synthesis, crystal structures, magnetism, oxidative and hydrolytic cleavage of pBR322 DNA. J. Inorg. Biochem. 2010, 104, 431-441. [CrossRef] [PubMed]

25. An, Y.; Liu, S.-D.; Deng, S.-Y.; Ji, L.-N.; Mao, Z.W. Cleavage of double-strand DNA by linear and triangular trinuclear copper complexes. J. Inorg. Biochem. 2006, 100, 1586-1593. [CrossRef]

26. An, Y.; Tong, M.L.; Ji, L.N.; Mao, Z.W. Double-strand DNA cleavage by copper complexes of 2,2'-dipyridyl with electropositive pendants. Dalton Trans. 2006, 17, 2066-2071. [CrossRef]

27. Johnstone, T.C.; Suntharalingam, K.; Lippard, S.J. The Next Generation of Platinum Drugs: Targeted Pt(II) Agents, Nanoparticle Delivery, and Pt(IV) Prodrugs. Chem. Rev. 2016, 116, 3436-3486. [CrossRef]

28. Brabec, V.; Hrabina, O.; Kasparkova, J. Cytotoxic platinum coordination compounds. DNA binding agents. Coord. Chem. Rev. 2017, 351, 2-31. [CrossRef]

29. Štarha, P.; Vancǒ, J.; Trávníček, Z. Platinum iodido complexes: A comprehensive overview of anticancer activity and mechanisms of action. Coord. Chem. Rev. 2019, 380, 103-135. [CrossRef]

30. Matesanz, A.I.; Hernandez, C.; Rodriguez, A.; Souza, P. Novel bis(thiosemicarbazones) of the 3,5-diacetyl-1,2,4-triazol series and their platinum(ii) complexes: Chemistry, antiproliferative activity and preliminary nephrotoxicity studies. Dalton Trans. 2011, 40, 5738-5745. [CrossRef]

31. Barve, A.; Kumbhar, A.; Bhat, M.; Joshi, B.; Butcher, R.; Sonawane, U.; Joshi, R. Mixed-Ligand Copper(II) Maltolate Complexes: Synthesis, Characterization, DNA Binding and Cleavage, and Cytotoxicity. Inorg. Chem. 2009, 48, 9120-9132. [CrossRef]

32. Massoud, S.S.; Louka, F.R.; Ducharme, G.T.; Fischer, R.C.; Mautner, F.A.; Vančo, J.; Herchel, R.; Dvořák, Z.; Trávníček, Z. Copper(II) complexes based on tripodal pyrazolyl amines: Synthesis, structure, magnetic properties and anticancer activity. J. Inorg. Biochem. 2018, 180, 39-46. [CrossRef] [PubMed]

33. Herchel, R.; Dvořák, Z.; Trávníček, Z.; Mikuriya, M.; Louka, F.R.; Mautner, F.A.; Massoud, S.S. Cobalt(II) and copper(II) covalently and non-covalently dichlorido-bridged complexes of an unsymmetrical tripodal pyrazolyl-pyridyl amine ligand: Structures, magnetism and cytotoxicity. Inorg. Chim. Acta 2016, 451, 102-110. [CrossRef] 
34. Lu, J.; Sun, Q.; Li, J.-L.; Jiang, L.; Gu, W.; Liu, X.; Tian, J.-L.; Yan, S.-P. Two water-soluble copper(II) complexes: Synthesis, characterization, DNA cleavage, protein binding activities and in vitro anticancer activity studies. J. Inorg. Biochem. 2014, 137, 46-56. [CrossRef] [PubMed]

35. Bavisotto, C.C.; Nikolic, D.; Gammaza, A.M.; Barone, R.; Cascio, F.L.; Mocciaro, E.; Zummo, G.; de Macairo, E.C.; Macario, A.J.; Cappelo, F.; et al. The dissociation of the Hsp60/pro-Caspase-3 complex by bis(pyridyl)oxadiazole copper complex (CubipyOXA) leads to cell death in NCI-H292 cancer cells. J. Inorg. Biochem. 2017, 170, 8-16. [CrossRef]

36. de Medeiros, W.M.T.Q.; de Medeiros, M.J.C.; Carvalho, E.M.; de Lima, J.A.; da Oliveira, S.V.; de Pontes, B.A.C.F.; da Silva, F.O.N.; Ellena, J.A.; de Rocha, O.H.A.; de Sousa, E.H.S.; et al. A vanillin-based copper(II) metal complex with a DNA-mediated apoptotic activity. RSC Adv. 2018, 8, 16873-16886. [CrossRef]

37. Erxleben, A. Interactions of copper complexes with nucleic acids. Chem. Rev. 2018, 360, 92-121. [CrossRef]

38. Montagner, D.; Fresch, B.; Browne, K.; Gandian, V.; Erxleben, A. A Cu(II) complex targeting the translocator protein: In vitro and in vivo antitumor potential and mechanistic insights. Chem. Commun. 2017, 53, 134-137. [CrossRef]

39. Deka, B.; Sarkar, T.; Banerjee, S.; Kumar, A.; Mukherjee, S.; Deka, S.; Sailkia, K.K.; Hussain, A. Novel mitochondria targeted copper(II) complexes of ferrocenyl terpyridine and anticancer active 8-hydroxyquinolines showing remarkable cytotoxicity, DNA and protein binding affinity. Dalton Trans. 2017, 46, 396-409. [CrossRef]

40. Dam, J.; Ismail, Z.; Kurebwa, T.; Ganger, N.; Harmse, L.; Marques, H.M.; Lemmerer, A.; Bode, M.L.; de Koning, C.B. Synthesis of copper and zinc 2-(pyridin-2-yl)imidazo[1,2-a]pyridine complexes and their potential anticancer activity. Eur. J. Med. Chem. 2017, 126, 353-368. [CrossRef]

41. Kathiresan, S.; Mugesh, S.; Annaraj, J.; Murugan, M. Mixed-ligand copper(II) Schiff base complexes: The vital role of co-ligands in DNA/protein interactions and cytotoxicity. New J. Chem. 2017, 41, 1267-1283. [CrossRef]

42. Jopp, M.; Becker, J.; Becker, S.; Miska, A.; Gandin, V.; Marzano, C.; Schindler, S. Anticancer activity of a series of copper(II) complexes with tripodal ligands. Eur. J. Med. Chem. 2017, 132, 274-281. [CrossRef] [PubMed]

43. Rajendiran, V.; Karthik, R.; Palaniandavar, M.; Periasamy, V.S.; Akbarsha, M.A.; Srinag, B.S.; Krishnamurthy, H. Mixed-Ligand Copper(II)-phenolate Complexes: Effect of Coligand on Enhanced DNA and Protein Binding, DNA Cleavage, and Anticancer Activity. Inorg. Chem. 2007, 46, 8208-8221. [CrossRef] [PubMed]

44. Addison, A.W.; Rao, T.N.; Reedijk, J.; Rijin, J.V.; Verschoor, G.C. Synthesis, structure, and spectroscopic properties of copper(II) compounds containing nitrogen-sulphur donor ligands; the crystal and molecular structure of aqua[1,7-bis(Nmethylbenzimidazol-2'-yl)-2,6-dithiaheptane]copper(II) perchlorate. J. Chem. Soc. Dalton Trans. 1984, 1349-1356. [CrossRef]

45. Halfen, J.A.; Uhan, J.M.; Fox, D.C.; Mehn, M.P.; Que, L., Jr. Copper(II) Complexes of Pyridyl-Appended Diazacycloalkanes: Synthesis, Characterization, and Application to Catalytic Olefin Aziridination. Inorg. Chem. 2000, 39, 4913-4920. [CrossRef]

46. Hathaway, B.J.; Wilkinson, G.; Gillard, R.D.; McCleverty, J.A. (Eds.) Comprehensive Coordiqnation Chemistry; Pergamon Press: Oxford, UK, 1987; Volume 5, p. 533.

47. Mautner, F.A.; Louka, F.R.; LeGuet, T.; Massoud, S.S. Pseudohalide copper(II) complexes derived from polypyridyl ligands: Synthesis and characterization. J. Mol. Struct. 2009, 919, 196-203. [CrossRef]

48. Mautner, F.A.; Fischer, R.C.; Torvisco, A.; Henary, M.M.; Milner, A.; DeVillier, H.; Karsili, T.N.V.; Louka, F.R.; Massoud, S.S. Steric Effects of Alkyl Substituents at N-Donor Bidentate Amines Direct the Nuclearity, Bonding and Bridging Modes in Isothiocyanato-Copper(II) Coordination Compounds. Crystals 2019, 9, 38. [CrossRef]

49. Mautner, F.A.; Albering, J.H.; Vicente, R.; Louka, F.R.; Gallo, A.A.; Massoud, S.S. Copper(II) complexes derived from tripodal tris[(2-ethyl-(1-pyrazolyl)]amine. Inorg. Chim. Acta 2011, 365, 290-296. [CrossRef]

50. Geary, W.J. The use of conductivity measurements in organic solvents for the characterisation of coordination compounds. Coord. Chem. Rev. 1971, 7, 81-122. [CrossRef]

51. Pérez, V.; Monsalvo, I.; Demare, P.; Gómez-Vidales, V.; Regla, I.; Castillo, I. Dicopper(II) complexes of chiral C2-symmetric diamino-bis(2-methylpyridyl) and diamino-bis(2-methylbenzimidazolyl) ligands. Inorg. Chem. Comm. 2011, 14, 389-391. [CrossRef]

52. Fry, F.H.; Fischmann, A.J.; Belousoff, M.J.; Spiccia, L.; Brügger, J. Kinetics and Mechanism of Hydrolysis of a Model Phosphate Diester by $\left[\mathrm{Cu}\left(\mathrm{Me}_{3} \mathrm{tacn}\right)\left(\mathrm{OH}_{2}\right)_{2}\right]^{2+}\left(\mathrm{Me}_{3} \mathrm{tacn}=1,4,7-\right.$ Trimethyl-1,4,7-triazacyclononane). Inorg. Chem. 2005, 44, 941-950. [CrossRef]

53. Li, F.-Z.; Feng, F.; Yu, L.; Xie, J.-q. The Metallomicelle of Lanthanide Metal (Ce, La) Aza-Macrocyclic Complexes with a Carboxyl Branch: The Catalytic Activity and Mechanism in the Hydrolysis of a Phosphate Diester. Solut. Chem. 2014, 43, 1331-1343. [CrossRef]

54. Leichnitz, S.; Heinrich, J.; Kulak, N. A fluorescence assay for the detection of hydrogen peroxide and hydroxyl radicals generated by metallonucleases. Chem. Commun. 2018, 54, 13411-13414. [CrossRef]

55. Zhao, G.; Chasteen, N.D. Oxidation of Good's buffers by hydrogen peroxide. Anal. Biochem. 2006, 349, 262-267. [CrossRef] [PubMed]

56. Heinrich, J.; Stubbe, J.; Kulak, N. Cu(II) complexes with hydrazone-functionalized phenanthrolines as self-activating metallonucleases. Inorg. Chim. Acta 2018, 481, 79-86. [CrossRef]

57. Puckett, C.A.; Ernsta, R.J.; Barton, J.K. Exploring the cellular accumulation of metal complexes. Dalton Trans. 2010, 39, 1159-1170. [CrossRef] 
58. Serda, M.; Kalinowski, D.S.; Mrozek-Wilczkiewicz, A.; Musiol, R.; Szurko, A.; Ratuszn, A.; Pantarat, N.; Kovacevic, Z.; Merlot, A.M.; Richardson, D.R.; et al. Synthesis and characterization of quinoline-based thiosemicarbazones and correlation of cellular iron-binding efficacy to anti-tumor efficacy. Bioorg. Med. Chem. Lett. 2012, 22, 5527-5531. [CrossRef]

59. Hertzberg, R.P.; Dervan, P.B. Cleavage of DNA with methidiumpropyl-EDTA-iron(II): Reaction conditions and product analyses. Biochemistry 1984, 23, 3934-3945. [CrossRef]

60. Stöbener, D.D.; Uckert, M.; Cuellar-Camacho, J.L.; Hoppensack, A.; Weinhart, M. Ultrathin Poly(glycidyl ether) Coatings on Polystyrene for Temperature-Triggered Human Dermal Fibroblast Sheet Fabrication. ACS Biomater. Sci. Eng. 2017, 3, $2155-2165$. [CrossRef]

61. Massoud, S.S.; Louka, F.R.; Tusa, A.F.; Bordelon, N.E.; Fischer, R.C.; Mautner, F.A.; Vančo, J.; Hošek, J.; Dvořákd, Z.; Trávníček, Z. Copper(II) complexes based on tripodal pyridyl amine derivatives as efficient anticancer agents. New J. Chem. 2019, 43, 6186-6196. [CrossRef]

62. He, J.; Sun, J.; Mao, Z.W.; Ji, L.N.; Sun, H.Z. Phosphodiester hydrolysis and specific DNA binding and cleavage promoted by guanidinium-functionalized zinc complexes. J. Inorg. Biochem. 2009, 103, 851-858. [CrossRef]

63. Dhar, S.; Reddy, P.A.N.; Chakravarty, A.R. Intramolecular nucleophilic activation promoting efficient hydrolytic cleavage of DNA by (aqua)bis(dipyridoquinoxaline)copper(II) complex. Dalton Trans. 2004, 5, 697-698. [CrossRef]

64. Gupta, T.; Dhar, S.; Nethaji, M.; Chakravarty, A.R. Bis(dipyridophenazine)copper(II) complex as major groove directing synthetic hydrolase. Dalton Trans. 2004, 1896-1900. [CrossRef] [PubMed] 